\title{
Cardiac tissue engineering and regeneration using cell-based therapy
}

\author{
This article was published in the following Dove Press journal: \\ Stem Cells and Cloning:Advances and Applications \\ 14 May 2015 \\ Number of times this article has been viewed
}

\author{
Mohammad T Alrefai ${ }^{1-3}$ \\ Divya Murali ${ }^{4}$ \\ Arghya Paul ${ }^{4}$ \\ Khalid M Ridwan ${ }^{1,2}$ \\ John M Connell',2 \\ Dominique Shum-Tim ${ }^{1,2}$ \\ 'Division of Cardiac Surgery, \\ ${ }^{2}$ Division of Surgical Research, McGill \\ University Health Center, Montreal, \\ QC, Canada; ${ }^{3}$ King Faisal Specialist \\ Hospital and Research Center, \\ Jeddah, Saudi Arabia; ${ }^{4}$ Department of \\ Chemical and Petroleum Engineering, \\ School of Engineering, University of \\ Kansas, Lawrence, KS, USA
}

Correspondence: Dominique Shum-Tim The Royal Victoria Hospital, Suite S8.73.B, 687 Pines Avenue West, Montreal, QC H3A IAI, Canada Tel +I 5 I4934 I934 ext 36873

Fax + I 5 I4843 I602

Email dshumtim@yahoo.ca
Abstract: Stem cell therapy and tissue engineering represent a forefront of current research in the treatment of heart disease. With these technologies, advancements are being made into therapies for acute ischemic myocardial injury and chronic, otherwise nonreversible, myocardial failure. The current clinical management of cardiac ischemia deals with reestablishing perfusion to the heart but not dealing with the irreversible damage caused by the occlusion or stenosis of the supplying vessels. The applications of these new technologies are not yet fully established as part of the management of cardiac diseases but will become so in the near future. The discussion presented here reviews some of the pioneering works at this new frontier. Key results of allogeneic and autologous stem cell trials are presented, including the use of embryonic, bone marrow-derived, adipose-derived, and resident cardiac stem cells.

Keywords: stem cells, cardiomyocytes, cardiac surgery, heart failure, myocardial ischemia, heart, scaffolds, organoids, cell sheet and tissue engineering

\section{Introduction}

It is well known that cardiovascular disease is a main cause of morbidity and mortality worldwide. ${ }^{1}$ Traditional medical and surgical therapies have had success in the treatment of many cardiovascular diseases, such as coronary artery disease and valvular diseases, but have had limited success in the therapy of damaged myocardium. Acute ischemic myocardial damage and chronic myocardial failure have been challenging conditions for which to provide an adequate long-term prognosis, although a recent study by Beltrami et al, ${ }^{2}$ demonstrated the ability of cardiac cells (cardiomyocytes) to divide after the occurrence of myocardial infarction (MI), and reentering the human cell cycle, but that may not be enough to provide the needed quantity of cells to restore the damage; the common belief before that study was that myocytes are unable to divide depending on the interpretation of the scar formation after the infarction.

This aspect widens our perspective of the management approach - from being dependent solely on medical, percutaneous coronary intervention (PCI) and a surgical approach, to include a new side for management that includes the application of stem cell therapy - as these conditions have so far exceeded the reach of traditional medicine. The use of stem cells and tissue engineering has been tested in the laboratories and clinical trials as a potential solution for future treatment.

When engineering tissue for use as a cardiovascular therapy, there are three main points to consider: scaffolds, cell sources, and signaling factors. 


\section{Scaffolds}

A "scaffold" is a substitute that provides a structural platform for a new cellular microenvironment that supports new tissue formation. It allows cell attachment, migration, differentiation, and organization that can aid in delivering soluble and bound biochemical factors. ${ }^{3}$

\section{Cell sources}

The choice of cells to populate a scaffold depends on the purpose of the new tissue graft. The new cells will synthesize the bulk of the mass of a tissue matrix, and will form the integrating connections with existing native tissues. They also maintain tissue homeostasis in general and provide various metabolic supports to other tissues and organs. Terminally differentiated cells have been used with variable degrees of success and there are some limitations to their use in tissue engineering, but stem cells, and more recently adult stem cells, have become the major players in most new tissue replacement strategies. ${ }^{4}$ Their favorable properties are being harnessed to drive most new tissue engineering processes. ${ }^{5}$

\section{Signaling factors}

Signaling factors can influence, and even direct, a new tissue's phenotype. Their application has been learned from signals observed during native tissue formation and they have direct and indirect effects on cell metabolism, migration, and organization. ${ }^{3}$

\section{Stem cell types used for cardiac repair}

Xenogeneic cells from nonhuman species have limitations in therapeutic strategies due to significant differences in antigens between species, potentially leading to graft rejection. Meanwhile, allogeneic cells from human donors are likely to have greater success after implantation. Allogeneic stem cells include umbilical cord-derived cells, fetal cardiomyocytes, and embryonic mesenchymal stem cells (EmSCs). These cells, however, are still potentially subjected to immune surveillance and rejection.

To eliminate the potential for allogeneic rejection, autologous cells from the same individual have become a central focus of stem cell research. This category of cells includes skeletal myoblasts, adipose-derived stem cells (AdSCs), resident cardiac stem cells (RCSCs) and bone marrow-derived (BMD) stem cells, such as $\mathrm{CD} 34^{+}$cells, induced pluripotent stem cells (iPSCs), mesenchymal stem cells (MSCs), multipotent adult progenitor cells, and endothelial progenitor cells (EPCs).

\section{Allogeneic sources}

\section{Fetal cardiomyocytes}

Fetal cardiomyocytes have significant potential for integration and regeneration. ${ }^{67}$ However, there are concerns, including immunogenicity, malignant potential, ethical questions, as well as limited availability. For these reasons, other cell types have surpassed this source as likely candidates for use in cardiac regenerative therapy.

\section{EmSCs}

EmSCs have broad potential to differentiate into cells from all three embryonic germ layers. In addition, intact cardiomyocytes have been produced in vitro as well. ${ }^{8}$ However, there are concerns about the use of EmSCs, due to their association with teratoma formation in rodent models ${ }^{9}$ and concerns about their potential malignant transformation. Moreover, the ethical and legal issues surrounding the use of human EmSCs have obstructed further exploration and shifted the existing attention onto other alternative sources for stem cell therapy in cardiac repair.

\section{Human umbilical cord blood-derived cells}

Human umbilical cord blood-derived cells are presently used for repopulating bone marrow in patients treated for bone marrow illnesses such as acute leukemia. Human cord blood contains a big number of non-hematopoietic stem cells that show fewer class II human leukocyte antigens and appears not to trigger an immune response, thus dropping the risk of rejection. This reduced immunological activity provides a striking option for regenerative therapy. ${ }^{10} \mathrm{~A}$ significant reduction in infarct size has also been shown after intramyocardial injection of human cord blood derived cells in animal models. ${ }^{11}$

\section{Autologous sources AdSCs}

AdSCs have been considered as a source of adult stem cells for cardiac repair. Adipose tissue includes a heterogeneous mixture of MSCs, hematopoietic stem cells, and EPCs. Consequently, the major clinical advantages of this type of cell is their availability, easy harvesting, and relatively low cost. Preclinical studies have shown that AdSCs are associated with improvement in ventricular function in animal models of MI. The mechanism of neoangiogenesis formation has hypothesized paracrine effects as a possible mechanism of action for AdSCs. ${ }^{12,13}$

\section{Skeletal myoblasts}

Skeletal myoblasts can be harvested by muscle biopsy from the individual and grafted to cardiac tissue. Preclinical animal studies have verified their ability to engraft, create 
myotubules, and improve cardiac function after transfer into infarcted myocardium. ${ }^{14}$ Clinical human trials such as the Myoblast Autologous Grafting in Ischemic Cardiomyopathy (MAGIC) trial and others have demonstrated that epicardial injection of skeletal myoblasts during coronary artery bypass graft (CABG) surgery is feasible with likely functional benefits (see Table 1 for study summaries). ${ }^{15,16}$ A major limitation, however, is that they remain devoted to the skeletal muscle lineage and have been associated with arrhythmias due to separation of cardiomyocytes by islands of skeletal muscle cells, therefore interfering with the propagation of electrical potentials. $^{15}$

\section{BMD stem cells}

BMD stem cells are widely studied due to their versatility and ease of collection. Of these, the most frequently tested adult stem cells are BMD mononuclear cells. Encouraging results have been reported in animal models of ischemic heart failure. ${ }^{17}$

\section{iPSCs}

"iPSCs" are autologous adult cells that can be converted into pluripotent cells. Through specific alterations, adult cells can be reprogrammed to express embryonic genes, allowing them to differentiate into tissues other than their specific lineage.

Table I Clinical effects of cell therapy for acute or chronic heart failure with different types of stem cells

\begin{tabular}{|c|c|c|c|}
\hline Trial & Cell source & Route of delivery & Effect on LV function \\
\hline TOPCARE-AMI ${ }^{77}$ & BMDs and CPCs & Intracoronary & No change \\
\hline $\mathrm{BOOST}^{79}$ & BMDs & Intracoronary & Positive \\
\hline REPAIR-AMI ${ }^{82}$ & BMDs & Intracoronary & Positive \\
\hline REGENT $^{83}$ & BMDs & Intracoronary & No significant change \\
\hline MYSTAR $^{84}$ & BMDs & Intracoronary/intramyocardial & Positive \\
\hline SWISS-AMI 85 & BMDs & Intracoronary & No change \\
\hline LEUVEN-AMI200 & BMDs & Intracoronary & No change \\
\hline ASTAMI ${ }^{80}$ & BMDs & Intracoronary & No change \\
\hline FINCELL 201 & BMDs & Intracoronary & Positive \\
\hline $\mathrm{HEBE}^{202}$ & BMDs & Intracoronary & No change \\
\hline TIME $^{203}$ & BMDs & Intracoronary & No change \\
\hline Late-TIME ${ }^{87}$ & BMDs & Intracoronary & No change \\
\hline APOLLO STUDY70 & AdSCs & Intracoronary & Positive \\
\hline PRECISE $^{89}$ & AdSCs & Transendocardial & No change \\
\hline TOPCARE-CHD ${ }^{92}$ & BMDs or CPCs & Intracoronary & No change \\
\hline FOCUS-CCTRN ${ }^{204}$ & BMDs & Transendocardial & No change \\
\hline Dib et $\mathrm{al}^{16}$ & Skeletal myoblasts & Transepicardial & Positive \\
\hline MAGIC 15 & Skeletal myoblasts & Transepicardial & No change \\
\hline SEISMIC 205 & Skeletal myoblasts & Transendocardial & No change, with positive trend \\
\hline CAuSMIC 206 & Skeletal myoblasts & Transendocardial & Positive \\
\hline Stamm et $\mathrm{al}^{72}$ & BMDs & Transepicardial & Positive \\
\hline Ang et $\mathrm{al}^{207}$ & BMDs & Transepicardial/intracoronary & No change \\
\hline STAR-heart ${ }^{94}$ & BMDs & Intracoronary & Positive \\
\hline TOPCARE-DCM 95 & BMDs & Intracoronary & Positive \\
\hline АСТ34-CMI208 & CPCs & Intramyocardial & Positive \\
\hline POSEIDON ${ }^{93}$ & $\mathrm{BMD}$ & Transendocardial & No change \\
\hline $\mathrm{SCIPIO}^{28}$ & RCSCs & Intracoronary & Positive \\
\hline CADUCEUS $^{88}$ & Cardiospheres & Intracoronary & No change \\
\hline C-CURE 209 & RCSCs & Transendocardial & Positive \\
\hline
\end{tabular}

Abbreviations: ACT34-CMI, Autologous Cellular Therapy CD34 - Chronic Myocardial Ischemia; AdSCs, adipose-derived stem cells; APOLLO, AdiPOse-derived Stem ceLLs in the treatment of patients with ST-elevation myOcardial infarction; ASTAMI, Autologous Stem-cell Transplantation in Acute Myocardial Infarction; BMDs, bone marrow-derived stem cells; BOOST, BOne marrOw transfer to enhance ST-elevation infarct regeneration; C-CURE, Cardiopoietic stem Cell therapy in heart failURE; CADUCEUS, CArdiosphere-Derived aUtologous Stem CElls to reverse ventricUlar dySfunction; CAuSMIC, CAtheter-based delivery of aUtologous Skeletal Myoblasts for Ischemic Cardiomyopathy; CPC, circulating progenitor cells; FINCELL, FINnish stem CELL trial; FOCUS-CCTRN, First Mononuclear Cells injected in the United States conducted by the CCTRN [Cardiovascular Cell Therapy Research Network]; HEBE, Multicenter, randomized trial of intracoronary infusion of autologous mononuclear bone marrow cells or peripheral mononuclear blood cells after primary percutaneous coronary intervention (PCI); LateTIME, Use of Adult Autologous Stem Cells in Treating People 2 to 3 Weeks after having a Heart Attack; LEUVEN-AMI, Leuven acute myocardial infarction; LV, left ventricular; MAGIC, Myoblast Autologous Grafting in Ischemic Cardiomyopathy; MYSTAR, MYocardial STem cell Administration after acute myocardial infaRction; POSEIDON, Comparison of Allogeneic versus Autologous Bone Marrow-Derived Mesenchymal Stem Cells Delivered by Trans-Endocardial Injection in Patients with Ischemic Cardiomyopathy; PRECISE, AdiPose-deRived stEm and Regenerative Cells In the Treatment of Patients with non revaScularizable ischEmic myocardium; RCSCs, resident cardiac stem cells; REGENT, Myocardial REGENeraTion by intracoronary infusion of selected population of stem cells in acute myocardial infarction; REPAIR-AMI, Reinfusion of Enriched Progenitor cells And Infarct Remodeling in Acute Myocardial Infarction; SCIPIO, Stem Cell Infusion in Patients with Ischemic cardiOmyopathy; SEISMIC, Safety and Effects of Implanted (Autologous) Skeletal Myoblasts (MyoCell) Using an Injection Catheter; STAR-heart, The acute and long-term effects of intracoronary Stem cell Transplantation in patients with chronic heARt failure; SWISSAMI, SWiss Multicenter Intracoronary Stem cells Study in Acute Myocardial Infarction; TIME, Timing In Myocardial infarction Evaluation; TOPCARE-AMI, Transplantation of Progenitor Cells and Regeneration Enhancement in Acute Myocardial Infarction; TOPCARE-CHD, Trans-Coronary Transplantation of Functionally Competent BMD Stem Cells; TOPCARE-DCM, Selective Intracoronary Bone Marrow-Derived Progenitor Cell Infusion in Patients with Non-Ischemic Dilated Cardiomyopathy. 
Interestingly, a recent publication has led to the discovery of a cardiac progenitor population of cells expressing both platelet-derived growth factor receptor-alpha and kinase insert domain receptor derived from human iPSCs that can give rise to smooth muscle cells (SMCs), cardiomyocytes, and vascular endothelial cells (ECs). ${ }^{18}$ Also, vascular ECs from human iPSCs can be attained from several distinct progenitor populations.

\section{RCSCs}

RCSCs have recently been discovered with great interest. Previously, the heart was considered to lack self-renewal capabilities as a terminally differentiated organ. Evidence has now shown, however, that the heart demonstrates continuous cell division following various injuries; for example, post-MI. ${ }^{2}$ Several studies have addressed, identified, and isolated RCSCs, which are capable of differentiating into multiple cell types, such as cardiomyocytes or vascular SMCs (VSMCs). ${ }^{19,20}$ Reduction in the infarct size and improvement of left ventricular (LV) function were noticed in rodent models of MI after RCSC culture and injection. ${ }^{21}$ These cells are an attractive option for cardiac repair. However, effective harvesting techniques need to be perfected (see Table 1 for study summaries).

The best-characterized and most well-studied RCSC population is c-kit $/$ Lin $^{-}$cells, originally described in the rat heart. ${ }^{19}$ The c-kit ${ }^{+} / \mathrm{Lin}^{-} \mathrm{RCSCs}$, isolated and expanded in culture, exhibit all the properties of induced stem cells. When injected into the injured myocardium, they were shown capable of restoring the cardiac pattern and function in various animal models of ischemic heart model, albeit to a variable extent. ${ }^{22-24}$ Human c-kit ${ }^{+}$cells have also recently been tested as a potential therapy in patients suffering from ischemic cardiomyopathy with promising results. ${ }^{19,24-28}$

\section{Origin, production, and purification of cardiac stem cells}

Since 1960, different experiments and discoveries in the field of stem cells have been made. Emerging clinical application trials started to evolve in the past 15 years and include but are not limited to the study of cardiac regeneration.

\section{Embryologic development of stem cells in the heart}

Different theories addressed the origin of stem cells in the heart. The origins of the cells in the heart may affect organ function, which implies that cells for tissue engineering and regenerative medicine should be selected cautiously.
The myocardial cells in the adult heart originate from mesodermal precursors during the embryonic period of the heart's growth. Signaling pathways orchestrate the formation of the first and second heart fields, ${ }^{29}$ which become cardiomyocytes, and the subsequent growth of the four-chambered heart from a linear heart tube. ${ }^{30,31}$ After the early framework for the heart is formed, some mesodermal cells from the proepicardium are enrolled to form the epicardium, the single layer of cells enveloping the heart. ${ }^{32}$

Next, in transition from an epithelial to mesenchymal layer, epicardial cells become migratory mesenchymal cells. These cells enter the underlying myocardium and differentiate into VSMCs as well as fibroblasts of the vascular interstitium and adventitia.

While the origin of the coronary endothelium is controversial, the present understanding is that this endothelium has a well-defined progenitor population of SMCs and fibroblasts in the proepicardium..$^{33,34}$ It is interesting that only after the main structure of the coronaries is established do the ECs conquer the aorta and create the coronary circulation. $^{35}$

\section{Differentiation of stem cells into cardiomyocytes}

The derivation of cardiomyocytes from human pluripotent stem cells follows a distinct developmental lineage throughout mesoderm induction. There has been a recent increase in the understanding of this process since the ability to derive cardiomyocytes from human EmSCs and iPSCs has driven a transition from using pluripotent cells to form cardiomyocytes for tissue engineering ${ }^{36}$ (summarized in Figure 1). The use of cardiomyocytes was first introduced when neonatal rat ventricular cardiomyocytes, which were developed for cardiac tissue engineering, ${ }^{34}$ were seeded into gel-foam and implanted onto an infarcted adult rat heart. ${ }^{35}$

Differentiation protocols for human EmSCs to cardiomyocytes involve adding bone morphogenetic protein 4 (BMP4) and recombinant human activin A to induce the cardiac mesoderm to reproduce the main foundations of embryonic development. ${ }^{18,37,38}$ Laflamme et a $1^{18}$ produced cardiomyocyte populations with over $50 \%$ cardiac purity (consisting of nodal cells, ventricular cells, and atrial cells). In this protocol, they induced endogenous expression of recognized Wnt ligands, and after mesodermal Wnt induction, successful cardiac differentiation requires subsequent inhibition of this pathway. ${ }^{39}$ This biphasic signaling profile, which normally occurs during development, ${ }^{40,41}$ offers an approach to evaluate the efficiency of cardiac differentiation 


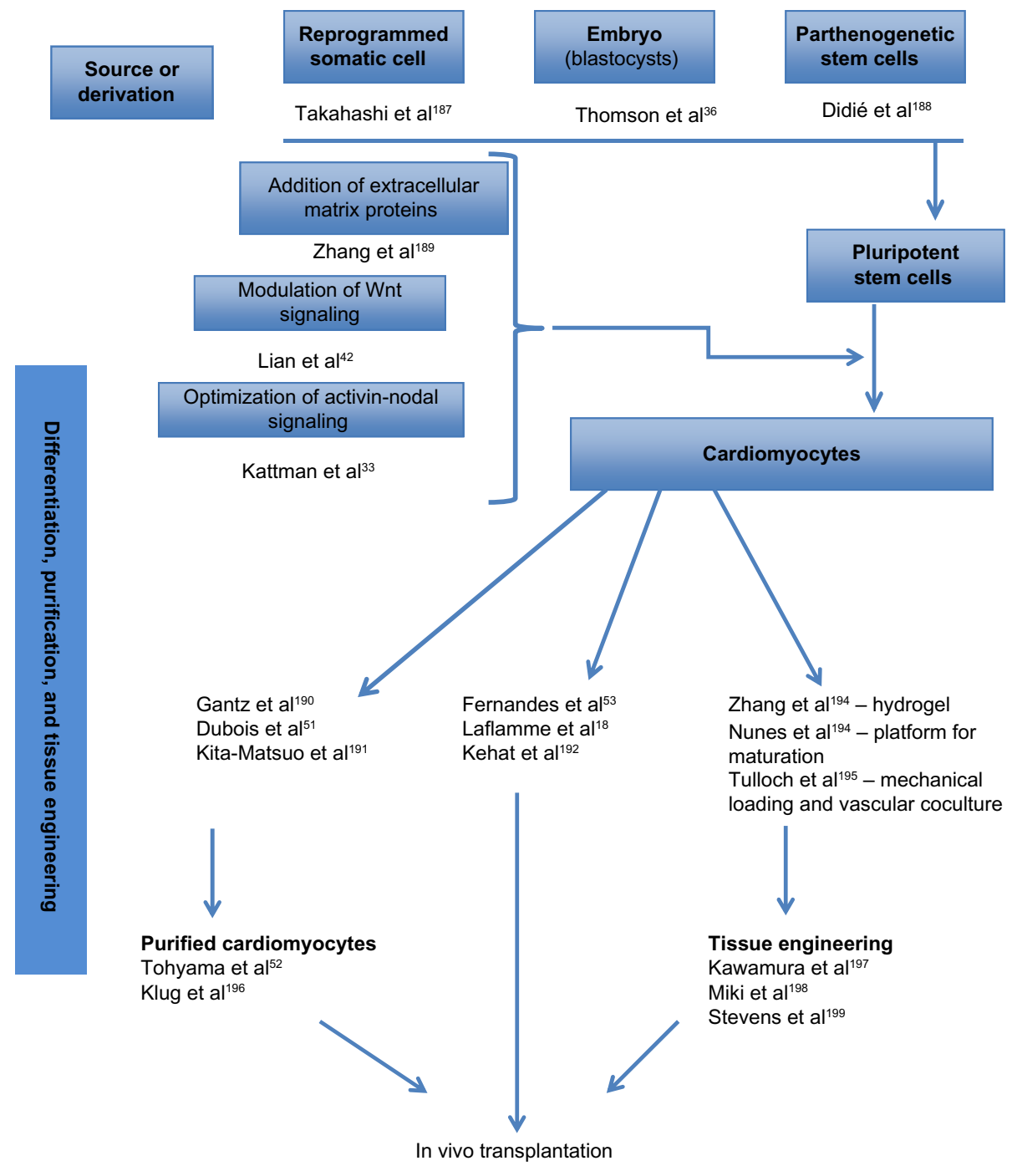

Figure I Progression of stem cells in vitro into cardiomyocytes for in vivo transplantation.

in different human EmSC and human iPSC lines and can be boosted by the addition of exogenous Wnt3a followed by inhibition of Wnt signaling with dickkopf-related protein 1 (DKK1) to increase cardiogenesis. ${ }^{39}$

Yang et $\mathrm{al}^{37}$ developed a different approach mimicking the three-dimensional (3D) setting of an evolving embryo using small cell groups called "embryoid bodies". These cells are exposed to basic fibroblast growth factor (bFGF), activin A, BMP4, vascular endothelial growth factor (VEGF), and, after mesodermal induction, DKK1 in a hypoxic environment for 10-12 days. A positive cardiovascular progenitor population expressing kinase insert domain receptor and platelet-derived growth factor receptor-alpha could be isolated on the 4th day, which revealed a differentiation of greater than $50 \%$ cardiac troponin $\mathrm{T}(\mathrm{cTnT})^{+}$cardiomyocytes in multiple lines of human EmSC and human iPSCs. ${ }^{33}$ Progenitor cardiovascular cells derived using this protocol also give rise to low levels of ECs $\left(\mathrm{CD} 31^{+}\right)$, fibroblasts (discoidin domain receptor 2 [DDR2 $]^{+}$), and VSMCs.

Another approach used the glycogen synthase kinase 3 (GSK3) inhibitor to activate Wnt/ $\beta$-catenin signaling and mesoderm differentiation, which yielded high levels of cardiogenesis to produce greater than $80 \%$ cardiomyocytes. ${ }^{42}$

An alternative approach uses transdifferentiation and reprogramming of fibroblasts directly into cardiomyocytes at the in vivo stage, using gene therapy, avoiding the pluripotent stage ${ }^{43,44}$ However, reproducing this high-yield work has proven to be a challenge, ${ }^{45}$ with very few transduced cells demonstrating contractile activity and several of these cells demonstrating only a partially reprogrammed, cardiomyocyte-like phenotype. ${ }^{46}$ This approach, though inefficient at this time, will is likely to have potential in the future as therapy for patients who are not surgical candidates for revascularization using tissue-engineered replacement. 


\section{Cardiac purity after differentiation}

Once differentiation has been achieved, there are several strategies to improve the yield and the purity of the tissue sample. One proposed protocol involved Percoll density gradient centrifugation..$^{18}$ This, however, reveled an injury to the cardiomyocytes and low survival rate at transplantation stage. Since then, multiple studies have used different strategies using genetic selection in which a cardiac-specific agent drives expression of an antibiotic-resistance gene, permitting cardiomyocytes to last while other cell types are lost. ${ }^{4-49}$ Cell-sorting techniques have been developed for cardiac-specific surface markers including vascular cell adhesion molecule (VCAM1 $)^{50}$ and signal regulatory protein alpha (SIRPA). ${ }^{51}$

Another strategy used involved culturing cells in a lactaterich medium that would eradicate or kill the cells that do not have enough mitochondria to survive (which most of the time are the non cardiac cells). $100 \%$ purity is hard to achieve. It has been reported that usage of unsorted cardiomyocytes with purities greater than $50 \%$ does not result in the formation of teratomas in animal model (rodent) studies, ${ }^{18}$ though occasional epithelial cysts have been detected..$^{53}$ These results are promising and imply that practically high-purity human EmSC- and iPSC-derived cardiomyocytes can be developed for clinical usage (summarized in Figure 1).

\section{Cell-based therapy for heart failure}

The treatment of post-MI heart failure remains an important and difficult task due to the high prevalence of post-MI heart failure and low levels of success with traditional medical and surgical therapies. ${ }^{54}$ An evolving strategy for the treatment of advanced ischemic cardiomyopathy is regenerative medicine. This involves the transplantation of pluripotent progenitor cells into the area of the infarcted myocardium with the expectancy of new functioning myocyte and vascular cell production.

The adult mammalian heart has been traditionally considered as a post-mitotic organ without intrinsic capacity for regeneration. Clinically, it behaves in this manner, with little recovery after ischemic damage. New understandings of cell biology, however, have caused a shift in such opinions and introduced a new avenue for potential therapy. Several reports have shown new cardiomyocyte cell-cycle production ranging from $0.0005 \%$ to $3 \%$ in normal adult hearts, ${ }^{55-57}$ and the dating of adult hearts with ${ }^{14} \mathrm{C}$ has also concluded that during a lifetime the human heart renews approximately $50 \%$ of its myocytes.$^{58}$ For these reasons, animal experiments have been performed and the interest generated from these experiments has led to clinical trials to evaluate stem cells as therapy for damaged adult human hearts. ${ }^{59}$

\section{Myocardial regeneration with allogeneic stem cell therapy}

Allogeneic cells can be grown in large quantities in advance, stored before their use, and made available at short notice, which make them a suitable option for highly prevalent diseases and will permit their use soon after an acute insult to either prevent or diminish pathological remodeling of the heart.

As yet unanswered questions about the use of allogeneic stem cells in the treatment of patients with acute myocardial injury need to be addressed, including what method of delivery is best for cell administration and what is the best cell population to deliver.

To be widely available and compatible with the current clinical standard of care for acute myocardial injury, an intracoronary method for delivery at the time of the primary revascularization is feasible. Catheter-based direct myocardial injection during revascularization surgery is also realistic.

For choice of cell populations, MSCs have been tested. These cells secrete a broad range of favorable cytokines. However, they also secrete factors that negatively modulate cardiomyocyte apoptosis, inflammation, scar formation, and pathological remodeling, as described by Ranganath et al. ${ }^{60}$ Also, only approximately $3 \%-4 \%$ of the cells delivered by intracoronary technique are retained in the myocardium, as reported by Dauwe and Janssens, ${ }^{61}$ as well as Teng et al, ${ }^{62}$ and MSCs can clump together, becoming entrapped in the microvasculature and obstructing entry into the myocardium.

Groups of allogeneic cell types in small aggregates known as "cardiospheres" have also been tested for therapy in a rat module of infarcted hearts. ${ }^{63}$ Allogeneic cardiospherederived cell (CDC) transplantation resulted in an improvement in fractional area change (12\%), ejection fraction (EF; $20 \%$ ), and fractional shortening (10\%), which was sustained for at least 6 months. Also, allogeneic CDCs stimulated regeneration through endogenous mechanisms, such as increased myocardial VEGF, insulin-like growth factor 1, and hepatocyte growth factor, and the recruitment of c-kit ${ }^{+}$ angiogenesis. ${ }^{63}$

One promising cell type to undergo testing for cell therapy is the RCSC, which has advanced beyond more primitive stem cells into a definite cardiac lineage but has not yet terminally differentiated or matured. Unlike other cell types such as BMD stem cells, which were mentioned by Abdel-Latif 
et $\mathrm{al}^{64}$ and Hofmann et al, ${ }^{65} \mathrm{RCSC}$ have a high tropism for the myocardium. When administered through the systemic circulation, the majority of RCSCs home to and nest in the damaged myocardium. ${ }^{66}$

Under appropriate conditions it is possible to replicate and expand RCSCs up to $1 \times 10^{11}$ cells without noticeable alteration of karyotype, loss of differentiating properties, or the phenotype of the differentiated progeny. ${ }^{67}$ These cells produce a range of beneficial pro-survival, anti-inflammatory, and cardiovascular regenerative growth factors, such as insulin-like growth factor 1, hepatocyte growth factor, activins, transforming growth factor-beta 1, and neuregulin-1, among others. ${ }^{68}$

It is postulated that it is because of the secretion of these regenerative factors that allogeneic stem cell therapy is successful. The factors produced by the allogeneic cells may stimulate endogenous stem cells of the target tissue while the transplanted cells themselves may survive only transiently. Thus, they might not directly participate in the production of progeny that contribute to the regenerated tissue. As a result, although the therapeutic cells are allogeneic, a lasting regenerative response may be autologous, carried out by host RCSCs. ${ }^{69}$

\section{Myocardial regeneration with autologous stem cell therapy}

Notwithstanding the values of autologous therapy, autologous cells require time for preparation and are not suited for highly prevalent diseases. A study done using an intracoronary infusion of AdSCs within hours of percutaneous revascularization in patients presenting with acute MI showed improved left ventricular ejection fraction (LVEF) with reduced scar formation. $^{70}$

Meanwhile, intracoronary injection of autologous BMD stem cells in patients with chronic heart failure had been shown to result in a corresponding 15\% improvement in EF and a $30 \%$ reduction in infarct size. ${ }^{71}$ Direct myocardial injection of $\mathrm{CD} 133^{+} \mathrm{BMD}$ stem cells into infarct border zones led to an improvement in LVEF from $37 \%$ to $47 \% .^{72}$

Also, cardiac stem cells have been shown to differentiate into multiple cell types, including cardiac myocytes, SMCs, and ECs. ${ }^{19}$ Infusion of autologous $\mathrm{Lin}^{-} / \mathrm{c}-\mathrm{kit}^{+}$cardiac stem cells into patients with post-MI resulted in LVEF improvement from $30.3 \%$ to $38.5 \%{ }^{28}$

In patients with refractory angina after conventional revascularization therapy, compelling evidence supporting stem cell therapy emerged from a randomized trial of catheter-based intramyocardial (endoventricular) injection of $\mathrm{CD} 34^{+}$progenitor cells, arranged following granulocyte colony stimulating factor-induced cell mobilization and "leukapheresis" (separation of white blood cells). ${ }^{73}$ It showed a trend in efficacy for endpoints such as fewer angina episodes, lowered nitroglycerin usage, improved exercise time, and improved functional class (as per the New York Heart Association Functional Classification) when compared with placebo. These results were similar to a recent trial (Efficacy and Safety of Targeted Intramyocardial Delivery of Auto CD34+ Stem Cells for Improving Exercise Capacity in Subjects With Refractory Angina [RENEW] study). ${ }^{73,74}$ In another trial, when patients were injected with bone marrow mononuclear stem cells endocardially, a trend toward improvement in chronic ischemia refractory to medical treatment was shown. Although there was no significant difference. ${ }^{75}$ In conjunction with coronary arterial bypass grafting, another study showed that intramyocardial injection of high-dose BMD mononuclear cells yields improved results compared with CABG alone. ${ }^{76}$ When $\mathrm{CD} 133^{+}$cells are injected through the transepicardial route during coronary surgery, there has been an improved LVEF and perfusion at 6 months post-operatively. ${ }^{72}$

\section{Clinical trials of cell therapy for heart failure}

Many studies have addressed the efficacy of stem cell injection in the cardiac disease patient. Here, we mention some of these studies and divide them depending on the timeframe of the intervention (summarized in Figure 2 and Tables 1 and 2).

\section{Acute heart failure \\ Intervention within $<7$ days \\ Transplantation of Progenitor Cells and Regeneration \\ Enhancement in Acute Myocardial Infarction (TOPCARE-AMI)}

This was a safety and feasibility trial targeting patients with acute MI successfully reperfused by stent implantation. They used an intracoronary infusion of circulating progenitor cells (CPCs) (approximately $245 \pm 72 \times 10^{6}$ Ficoll-separated, cultured CPCs) and bone marrow cells (approximately $10 \pm 7 \times 10^{6}$ Ficoll-separated BMD cells) 4 days after the infarction. It showed a trend of improvement in regional wall motion in the infarcted zone and reduction of endsystolic LV volume immediately after the injection as well as during the 4-month follow-up. The efficacy was similar between patients receiving BMD stem cells and patients receiving blood-derived $\mathrm{CPCs} .^{77}$ 


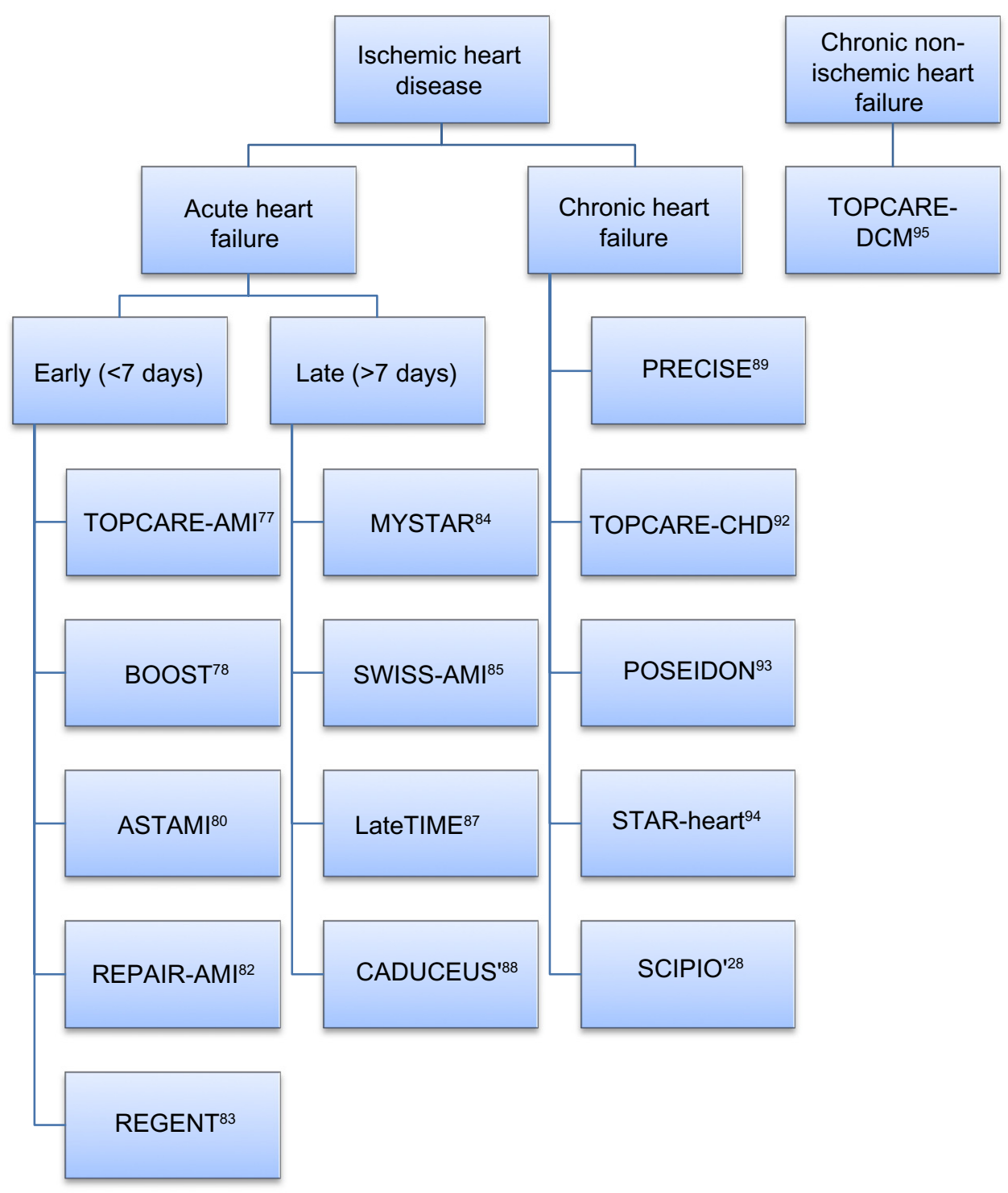

Figure 2 Clinical trials of cell therapy for acute and chronic, ischemic and nonischemic heart failure.

Abbreviations: ASTAMI, Autologous Stem-cell Transplantation in Acute Myocardial Infarction; BOOST, BOne marrOw transfer to enhance ST-elevation infarct regeneration; CADUCEUS, CArdiosphere-Derived aUtologous Stem CElls to reverse ventricUlar dySfunction; LateTIME, Use of Adult Autologous Stem Cells in Treating People 2 to 3 Weeks after having a Heart Attack; MYSTAR, MYocardial STem cell Administration after acute myocardial infaRction; POSEIDON, Comparison of Allogeneic versus Autologous Bone Marrow-Derived Mesenchymal Stem Cells Delivered by Trans-Endocardial Injection in Patients with Ischemic Cardiomyopathy; PRECISE, AdiPose-deRived stEm and Regenerative Cells In the Treatment of Patients with non revaScularizable ischEmic myocardium; REGENT, Myocardial REGENeraTion by intracoronary infusion of selected population of stem cells in acute myocardial infarction; REPAIR-AMI, Reinfusion of Enriched Progenitor cells And Infarct Remodeling in Acute Myocardial Infarction; SCIPIO, Stem Cell Infusion in Patients with Ischemic cardiOmyopathy; STAR-heart, The acute and long-term effects of intracoronary Stem cell Transplantation in patients with chronic heARt failure; SWISSAMI, SWiss Multicenter Intracoronary Stem cells Study in Acute Myocardial Infarction; TOPCARE-AMI, Transplantation of Progenitor Cells and Regeneration Enhancement in Acute Myocardial Infarction; TOPCARE-CHD, Trans-Coronary Transplantation of Functionally Competent BMD Stem Cells; TOPCARE-DCM, Selective Intracoronary Bone Marrow-Derived Progenitor Cell Infusion in Patients with Non-Ischemic Dilated Cardiomyopathy.

\section{BOne marrOw transfer to enhance}

\section{ST-elevation infarct regeneration (BOOST)}

This study targeted patients who had acute MI and had stent implanted using PCI. They had a transfusion of a single dose of autologous bone marrow stem cells through intracoronary route. The number of cells used was approximately $2.5 \times 10^{9}$ of unfractionated BMD cells. The results showed a slight improvement in LVEF of 7\%, which was, however, not sustained at 18 months. ${ }^{78,79}$

\section{Autologous Stem-cell Transplantation in Acute Myocardial Infarction (ASTAMI)}

This trial targeted patients with acute ST-segment elevation myocardial infarction (STEMI). They harvested autologous bone marrow cells, which were delivered through intracoronary injections during PCI for stent implantation. The number of cells used was approximately $7 \times 10^{7}$ Ficoll-separated BMD stem cells. In this trial, there was no improvement in LVEF at 6 months after delivery of injected cells. ${ }^{80}$ 
Table 2 Cells number and purification methods

\begin{tabular}{|c|c|c|}
\hline Trial & Cell source (number of cells used) & Separation/purification method \\
\hline \multirow[t]{2}{*}{ TOPCARE-AMI ${ }^{77}$} & CPCs $\left(245 \pm 72 \times 10^{6}\right)$ & Positive KDR/CDI05 \\
\hline & BMDs $\left(10 \pm 7 \times 10^{6}\right)$ & Ficoll centrifugation \\
\hline $\mathrm{BOOST}^{79}$ & BMDs $\left(2.5 \times 10^{9}\right)$ & Density gradient sedimentation, CD $34^{+}$flow cytometry \\
\hline ASTAMI $^{80}$ & BMDs $\left(7 \times 10^{7}\right)$ & Ficoll centrifugation \\
\hline REPAIR-AMI ${ }^{82}$ & BMDs $\left(2.4 \times 10^{8}\right)$ & Ficoll centrifugation \\
\hline \multirow[t]{2}{*}{ REGENT $^{83}$} & BMDs-CD $34^{+}\left(1.90 \times 10^{6}\right)$ & Ficoll centrifugation/ \\
\hline & BMDs $\left(1.78 \times 10^{8}\right)$ & Immunomagnetic monoclonal antibodies \\
\hline \multirow[t]{2}{*}{ MYSTAR $^{84}$} & BMDs E $\left(1.56 \pm 0.40 \times 10^{9}\right)$ & $\mathrm{COBE}^{\circledR}$ Spectra ${ }^{\mathrm{TM}}$ filter \\
\hline & BMDs L $\left(1.55 \pm 0.44 \times 10^{9}\right)$ & Fluorescence cell sorting \\
\hline \multirow[t]{2}{*}{ SWISS-AMI85 } & BMDs $\mathrm{E}\left(153 \times 10^{6}\right)$ & Ficoll centrifugation \\
\hline & BMDs L $\left(139.5 \times 10^{6}\right)$ & Anti-CD34 and CDI33 \\
\hline \multirow[t]{2}{*}{ LateTIME ${ }^{87}$} & BMDs $\left(150 \times 10^{6}\right)$ & Ficoll centrifugation \\
\hline & & Fluorescence cell sorting \\
\hline PRECISE $^{89}$ & $\operatorname{AdSCs}\left(42 \times 10^{6}\right)$ & Cytori Celution $^{\circledast}$ device $^{\mathrm{TM}}$ \\
\hline TOPCARE-CHD 92 & BMDs $\left(214 \pm 98 \times 10^{6}\right)$ & Ficoll centrifugation \\
\hline POSEIDON ${ }^{93}$ & Allogenic/Autologous BMDs $\left(20-100-200 \times 10^{6}\right)$ & Ficoll centrifugation \\
\hline STAR-heart ${ }^{94}$ & BMDs $\left(6.6 \pm 3.3 \times 10^{7}\right)$ & Ficoll centrifugation, $\mathrm{CD} 34^{+} / \mathrm{CD} / 33^{+}$ \\
\hline TOPCARE-DCM 95 & BMDs $\left(259 \pm 135 \times 10^{6}\right)$ & Ficoll centrifugation \\
\hline SCIPIO 28 & RCSCs (I million) & Immunomagnetic sorting with human CDII7 \\
\hline LEUVEN-AMI200 & BMDs $\left(172-304 \times 10^{6}\right)$ & Ficoll centrifugation \\
\hline FINCELL 201 & BMDs $\left(360 \times 10^{6}\right)$ & Ficoll centrifugation \\
\hline \multirow[t]{2}{*}{ HEBE ${ }^{202}$} & BMDs $\left(296 \pm 164 \times 10^{6}\right)$ & Lymphoprep density centrifugation \\
\hline & Blood $\left(287 \pm 137 \times 10^{6}\right)$ & \\
\hline TIME $^{203}$ & BMDs $\left(150 \times 10^{6}\right)$ & Ficoll centrifugation \\
\hline APOLLO $^{70}$ & $\operatorname{AdSCs}\left(17.4 \pm 4.1 \times 10^{6}\right)$ & Cytori Celution $^{\circledast}$ device $^{\mathrm{TM}}$ \\
\hline FOCUS-CCTRN 204 & BMDs $\left(100 \times 10^{6}\right)$ & Ficoll centrifugation, flow cytometry CD34, I 33 \\
\hline Dib et $\mathrm{al}^{16}$ & $\operatorname{SMs}\left(1-3 \times 10^{8}\right)$ & Anti-CD56 antibody staining \\
\hline MAGIC ${ }^{15}$ & SMs $\left(400-800 \times 10^{6}\right)$ & Flow cytometry $\mathrm{CD} 56^{+}$cells \\
\hline SEISMIC 205 & SMs $\left(586 \pm 193 \times 10^{6}\right)$ & Flow cytometry $\mathrm{CD} 56^{+}$cells \\
\hline CAuSMIC ${ }^{206}$ & SMs $\left(2 \times 10^{5}\right)$ & Anti-CD56 monoclonal antibodies \\
\hline Stamm et $\mathrm{al}^{72}$ & BMDs $\left(5.8 \times 10^{6}\right)$ & Magnetic separation with ferrite-conjugated antibody \\
\hline \multirow[t]{4}{*}{ Ang et a ${ }^{207}$} & BMDs IM $\left(84 \pm 56 \times 10^{6}\right)$ & Lymphoprep ${ }^{\mathrm{TM}}$ density centrifugation \\
\hline & BMDs IC $\left(115 \pm 73 \times 10^{6}\right)$ & \\
\hline & $\mathrm{CD} 34^{+} / \mathrm{CD} \mid 17^{+} \mathrm{IM}\left(142 \pm 166 \times 10^{3}\right)$ & \\
\hline & $\mathrm{CD} 34^{+} / \mathrm{CD} \mid \mathrm{I} 7^{+} \mathrm{IC}\left(254 \pm 254 \times 10^{3}\right)$ & \\
\hline АCT34-CMI 208 & $\operatorname{MSCs}\left(I-5 \times 10^{5}\right) / \mathrm{kg}$ & CD34+ fluorescence sorting \\
\hline CADUCEUS 88 & Cardiospheres $\left(12.5-25.0 \times 10^{6}\right)$ & $95 \%$ positive CDI 05 \\
\hline C-CURE 209 & BMDs $\left(600-1,200 \times 10^{6}\right)$ & $\begin{array}{l}\text { PCR of CD34, FABP4, SOX9, osteocalcin, and nestin } \\
\text { (exposed vs nonexposed to cardiac GF cocktail) }\end{array}$ \\
\hline
\end{tabular}

Abbreviations: ACT34-CMI, Autologous Cellular Therapy CD34 - Chronic Myocardial Ischemia; AdSCs, adipose-derived stem cells; APOLLO, AdiPOse-derived Stem ceLLs in the treatment of patients with ST-elevation myOcardial infarction; ASTAMI, Autologous Stem-cell Transplantation in Acute Myocardial Infarction; BMDs, bone marrowderived stem cells; BOOST, BOne marrOw transfer to enhance ST-elevation infarct regeneration; C-CURE, Cardiopoietic stem Cell therapy in heart failURE; CADUCEUS, CArdiosphere-Derived aUtologous Stem CElls to reverse ventricUlar dySfunction; CAuSMIC, CAtheter-based delivery of aUtologous Skeletal Myoblasts for Ischemic Cardiomyopathy; CPCs, circulating progenitor cells; E, early; FINCELL, FINnish stem CELL trial; FOCUS-CCTRN, First Mononuclear Cells injected in the United States conducted by the CCTRN [Cardiovascular Cell Therapy Research Network]; GF, growth factors; IC, intramyo cardial; IM, intra muscular; HEBE, Multicenter, randomized trial of intracoronary infusion of autologous mononuclear bone marrow cells or peripheral mononuclear blood cells after primary percutaneous coronary intervention (PCI); KDR, kinase insert domain receptor; L, late; LateTIME, Use of Adult Autologous Stem Cells in Treating People 2 to 3 Weeks after having a Heart Attack; LEUVEN-AMI, LEUVENAcute Myocardial Infarction; MAGIC, Myoblast Autologous Grafting in Ischemic Cardiomyopathy; MSCs, mesenchymal stem cells; MYSTAR, MYocardial STem cell Administration after acute myocardial infaRction; PCR, polymer chain reaction; POSEIDON, Comparison of Allogeneic versus Autologous Bone Marrow-Derived Mesenchymal Stem Cells Delivered by Trans-Endocardial Injection in Patients with Ischemic Cardiomyopathy; PRECISE, AdiPose-deRived stEm and Regenerative Cells In the Treatment of Patients with non revaScularizable ischEmic myocardium; REGENT, Myocardial REGENeraTion by intracoronary infusion of selected population of stem cells in acute myocardial infarction; REPAIR-AMI, Reinfusion of Enriched Progenitor cells And Infarct Remodeling in Acute Myocardial Infarction; RCSCs, resident stem cells; SCIPIO, Stem Cell Infusion in Patients with Ischemic cardiOmyopathy; SEISMIC, Safety and Effects of Implanted (Autologous) Skeletal Myoblasts (MyoCell) Using an Injection Catheter; SMs, skeletal myoblasts; STARheart, The acute and long-term effects of intracoronary Stem cell Transplantation in patients with chronic heARt failure; SWISS-AMI, SWiss Multicenter Intracoronary Stem cells Study in Acute Myocardial Infarction; TIME, Timing In Myocardial infarction Evaluation; TOPCARE-AMI, Transplantation of Progenitor Cells and Regeneration Enhancement in Acute Myocardial Infarction; TOPCARE-CHD, Trans-Coronary Transplantation of Functionally Competent BMD Stem Cells; TOPCARE-DCM, Selective Intracoronary Bone Marrow-Derived Progenitor Cell Infusion in Patients with Non-Ischemic Dilated Cardiomyopathy.

\section{Reinfusion of Enriched Progenitor cells And Infarct}

Remodeling in Acute Myocardial Infarction (REPAIR-AMI)

This was a randomized and double-blinded study targeting patients who had PCI after acute MI. They divided the population into two groups receiving bone marrow cells versus placebo infusion. The total number of cells used was estimated to be $2.4 \times 10^{8}$. The initial 4 months' result showed an increase in LVEF in the bone marrow group compared with in the 
placebo group. At the 2-year follow-up, cell-treated patients in this trial had had fewer myocardial ischemias and there were fewer patients who met the combined endpoint of death, MI, or need for revascularization. Although the results were not statistically significant, there was a trend toward sustained improvement in EF and LV end-systolic volume. ${ }^{81,82}$

\section{Myocardial REGENeraTion by intracoronary}

infusion of selected population of stem cells

in acute myocardial infarction (REGENT)

REGENT was a randomized, multicenter study targeting patients with acute STEMI within 12 hours of the symptoms, to assess the myocardial regeneration by intracoronary infusion of selected populations of BMD stem cells. They used autologous BMD cells and divided them into three groups: selected $\mathrm{CD} 4^{+}$group (median number of cells $1.90 \times 10^{6}$ ), nonselected bone marrow cell group (median number of cells $1.78 \times 10^{8}$ ), and placebo group. The treatment with BMD stem cells did not lead to a significant improvement in LVEF or LV volumes. However, there was a trend in favor of cell therapy in patients with the most severely impaired LVEF and prolonged periods between symptoms and revascularization. ${ }^{83}$

Intervention within $>7$ days

MYocardial STem cell Administration after

acute myocardial infaRction (MYSTAR)

The hypothesis relied on, is the injected stem cells homing which will be ideal 21 days after the incident of MI but not later than 42 days. They used autologous bone marrow stem cells by intracoronary and intramyocardial injections at two different timings. Patients were divided into four groups: early intracoronary nonselected BMD stem cells (between 21 and 42 days), early combined intracoronary with intramyocardial BMD stem cells, late (3 months) intracoronary injection, and late combined injections. The mean number of injected cells in the early group and late group was $1.56 \pm 0.40 \times 10^{9}$ and $1.55 \pm 0.44 \times 10^{9}$, respectively. The results showed that the early and late delivery of cells induced mild, but not clinically relevant, improvements. There was a reduction in infarct size and an improvement in LVEF at both 3 months and 9 to 12 months after acute myocardial ischemia. The main improvements in the early and late groups were an estimated $3.5 \%$ and $3.9 \%$, respectively, improvement in LVEF, as well as a $3.5 \%$ and $3.4 \%$, respectively, improvement in infarct size. ${ }^{84}$

\section{SWiss Multicenter Intracoronary Stem cells Study} in Acute Myocardial Infarction (SWISS-AMI)

In this trial, BMD mononuclear stem cells were injected through the intracoronary route for patients who had STEMI, received a successful PCI intervention within 24 hours, and had an EF of less than $45 \%$. They used an intracoronary injection of an estimated $153 \times 10^{6}$ and $139.5 \times 10^{6}$ of BMD stem cells in the early group (5-7 days) and in the late group (3-4 weeks), respectively. It showed that the infusion of BMD stem cells, either at 5-7 days or 3-4 weeks after acute MI did not improve LV function at 4 months. ${ }^{85}$

Use of Adult Autologous Stem Cells in Treating People 2 to 3 Weeks after having a Heart Attack (LateTIME)

This trial evaluated the use of bone marrow mononuclear (BMD) stem cells with infusion at 2 to 3 weeks after acute anterior-wall MI versus placebo in patients with EF less than $45 \%$ successfully treated with primary PCI. Single intracoronary infusion of $150 \times 10^{6}$ of autologous BMD stem cells was injected within 12 hours of aspiration and cell preparation. The results showed no substantial improvement in LVEF measured after 6 months. ${ }^{86,87}$

\section{CArdiosphere-Derived aUtologous Stem CElls to reverse ventricUlar dySfunction (CADUCEUS)}

This was a randomized prospective trial targeting patients within 2-4 weeks of acute MI with an LVEF of $25 \%-45 \%$. Cells were obtained from the right ventricular endocardium through biopsy. Patients received either a low dose $\left(12.5 \times 10^{6}\right)$ or a high dose $\left(25 \times 10^{6}\right)$ of cells versus a control group (which received no cells). The cells were introduced through the intracoronary route using an angioplasty catheter over a period of 15 minutes. This study was done to assess the safety of CDCs. There was a significant decrease in the scar size and increase in viable myocardium at 6 and 12 months in the treatment group compared with in the control group, but there was no significant difference between the two groups at 6 months in terms of EF improvement. ${ }^{88}$

\section{Chronic heart failure}

\section{AdiPose-deRived stEm and Regenerative Cells} In the Treatment of Patients with non revaScularizable ischEmic myocardium (PRECISE) PRECISE was a randomized clinical trial of AdSCs for patients with no revascularization option by either surgery or PCI. The autologous AdSCs were harvested by liposuction and the mean of the total number of cells used was $42 \times 10^{6}$ in the treatment group. This trial, which had an AdSCs group versus a placebo group, showed that harvesting and transendocardial injection of AdSCs are safe and feasible. Also, the treatment appeared to result in scar stabilization. ${ }^{89}$ However, data preceding this trial, by Perin et al, explored the transendocardial administration of BMD stem cells in patients with 
ischemic cardiomyopathy and a mean LVEF of less than $40 \% .^{90}$ There was no major improvement in LVEF at 6 or 12 months in the treated group when compared with control subjects. There was, however, a substantial improvement in exercise capacity, as well as ischemic burden, as measured by single-photon emission computed tomography (SPECT), found at 6 and 12 months. $^{91}$

\section{Transplantation of progenitor cells and recovery} of left ventricular function in patients with chronic ischemic heart disease (TOPCARE-CHD)

This study targeted patients with an MI of more than 3 months who were stable on medical therapy since the attack. Autologous BMD stem cells (mean number of $214 \pm 98 \times 10^{6}$ ) were injected through the intracoronary route. The study found that the treatment was associated with a reduction in natriuretic peptide serum levels (as natriuretic peptide serum levels are a solid marker for chronic heart failure) and improved the survival of patients with chronic heart failure post-MI. ${ }^{92}$

Percutaneous stem cell injection delivery effects on neomyogenesis: Comparison of Allogeneic versus Autologous Bone Marrow-Derived Mesenchymal Stem Cells Delivered by Trans-Endocardial Injection in Patients with Ischemic Cardiomyopathy (POSEIDON)

This trial targeted patients with ischemic cardiomyopathy with EF of less than 50\%. It compared autologous (extracted by bone marrow aspiration) and allogenic (extracted by bone marrow aspiration from healthy donors) MSCs. The researchers divided the population into three groups according to the number of infused cells: $20 \times 10^{6}$ for the first group, $100 \times 10^{6}$ for the second group, and $200 \times 10^{6}$ for the third group. Treatment was associated with lower rates of treatmentemergent serious adverse effects, including immunologic reactions. MSC injection favorably affected patient quality of life, functional capacity, and ventricular remodeling. ${ }^{93}$

\section{The acute and long-term effects of intracoronary} Stem cell Transplantation in patients with chronic heARt failure (STAR-heart)

This study included a large group of patients with chronic ischemic heart failure within a time interval of $8.5 \pm 3.2$ years between the infarct intervention and the admission to the clinical care. The study evaluated autologous BMD stem cells in patients with an LVEF of $35 \%$ or less and a remote history of MI. During this unblinded study, patients who refused cell therapy served as controls. The BMD stem cells were delivered into the infarct-related coronary artery through the intracoronary route and the estimated number of injected cells was $6.6 \pm 3.3 \times 10^{7}$. At 3 months, the treated group had had substantial improvements in cardiac index and calculated LVEF with an increase of almost 7\%. There was also a drop in New York Heart Association class and in both end-systolic $(\approx 15 \mathrm{~mL})$ and end-diastolic $(\approx 10 \mathrm{~mL})$ ventricular volumes. These improvements persisted at 12 and 60 months after treatment, while no changes were noted in the control group. Also, the mortality rate of the treated group was remarkably lower than that of the control group $(0.75 \%$ vs $3.68 \%$ per year). This trial provided the first long-term evidence that cell therapy can considerably affect mortality in heart failure patients. ${ }^{94}$

\section{Stem Cell Infusion in Patients with Ischemic cardiOmyopathy (SCIPIO)} SCIPIO was the first randomized, open-label, Phase I clinical trial in humans to evaluate autologous $\mathrm{c}^{-} / \mathrm{kit}^{+} \mathrm{RCSCs}$ in patients with ischemic heart failure (LVEF equal to or less than $40 \%$ ) at an average of 3.7 years post-MI. RCSCs were harvested from the right atrial appendage during $\mathrm{CABG}$ in 33 patients (20 RCSC-treated vs 13 control subjects), with $1 \times 10^{6}$ cells injected per patient. The RCSC-treated patients received an intracoronary infusion of cells at a mean of 113 days after CABG. In the treated group, cardiac magnetic resonance imaging showed an increase in LVEF at 4 months (from $27.5 \% \pm 1.6 \%$ to $35.1 \% \pm 2.4 \%[P=0.004, \mathrm{n}=8]$ ) and at 12 months $(41.2 \% \pm 4.5 \%[P=0.013, \mathrm{n}=5])$. Infarct size, measured as late gadolinium enhancement by perfusion magnetic resonance imaging, decreased by $-9.8 \pm 3.5 \mathrm{~g}$ after RCSCs infusion at 12 months in six patients who completed 1-year follow-up. In the treated group, the LV infarcted mass decreased by $-14.7 \pm 3.9 \mathrm{~g}$ and LV non-infarcted mass increased by $+31.5 \pm 11.0 \mathrm{~g}$ at 12 months' follow-up. The study concluded that the improvements in LVEF, decrease in infarcted LV mass, and increase in non-infarcted LV mass seen at 4 months and persisting for up to 12 months in a subgroup of patients were consistent with cardiac regeneration. ${ }^{27}$

\section{Chronic nonischemic heart failure} Transplantation of progenitor cells and recovery of left ventricular function in patients with nonischemic dilatative cardiomyopathy (TOPCARE-DCM)

This trial targeted patients who had nonischemic dilated cardiomyopathy with an EF of less than $40 \%$ and LV enddiastolic diameter of more than $60 \mathrm{~mm}$ who were stable for at least 6 months of medical therapy. The patients received autologous an estimated $259 \pm 135 \times 10^{6}$ of BMD stem cells. The 
researchers used intracoronary infusion by PCI. The results of this trial were correlated with improvements in cardiac contractility and intracoronary circulation flow in patients with dilated cardiomyopathy, as well as a significant improvement in natriuretic peptide serum levels, although the latter was noticed after the 1-year follow-up but not before. ${ }^{95}$

\section{Cardiac tissue engineering}

Cardiac muscles, present in the pericardium, heart walls, and valves, form a dense network of striated and cross-linked cells. The muscle contains sarcomeres with sliding filaments of actin and myosin. The electrical and mechanical gap junctions permit the heart to contract and relax in a coordinated fashion and conduct these impulses throughout the heart walls through the arteries and ventricles. ${ }^{96}$

The major diseases originating from cardiac muscles include MI, arrhythmias, ventricular dilatation, valvular diseases, and heart failure. It has been reported that the lack of donor organs, scar tissue formation, calcification of grafts, degradation, and inflammation of the affected tissue microenvironment are the most common problems associated with cardiac diseases. To overcome these hurdles, cardiac tissue engineering aims at assembling tissue constructs that can restore basic cardiac function by incorporating cellular components within scaffolds which in turn provide a framework of optimal structural, mechanical, and electrophysiological properties. ${ }^{97,98}$

Initially, cellular therapy involved the injection of "naked" cells into the site of injury, and although this technique has shown some promise in experiments, ${ }^{80,90}$ low cellular retention and engraftment rate limits its potential use for complete restoration of cardiac function. ${ }^{18,99,100}$

Recently, much emphasis has been placed on tissue engineering methods that mimic the biological and biomechanical components of the native myocardial tissue and

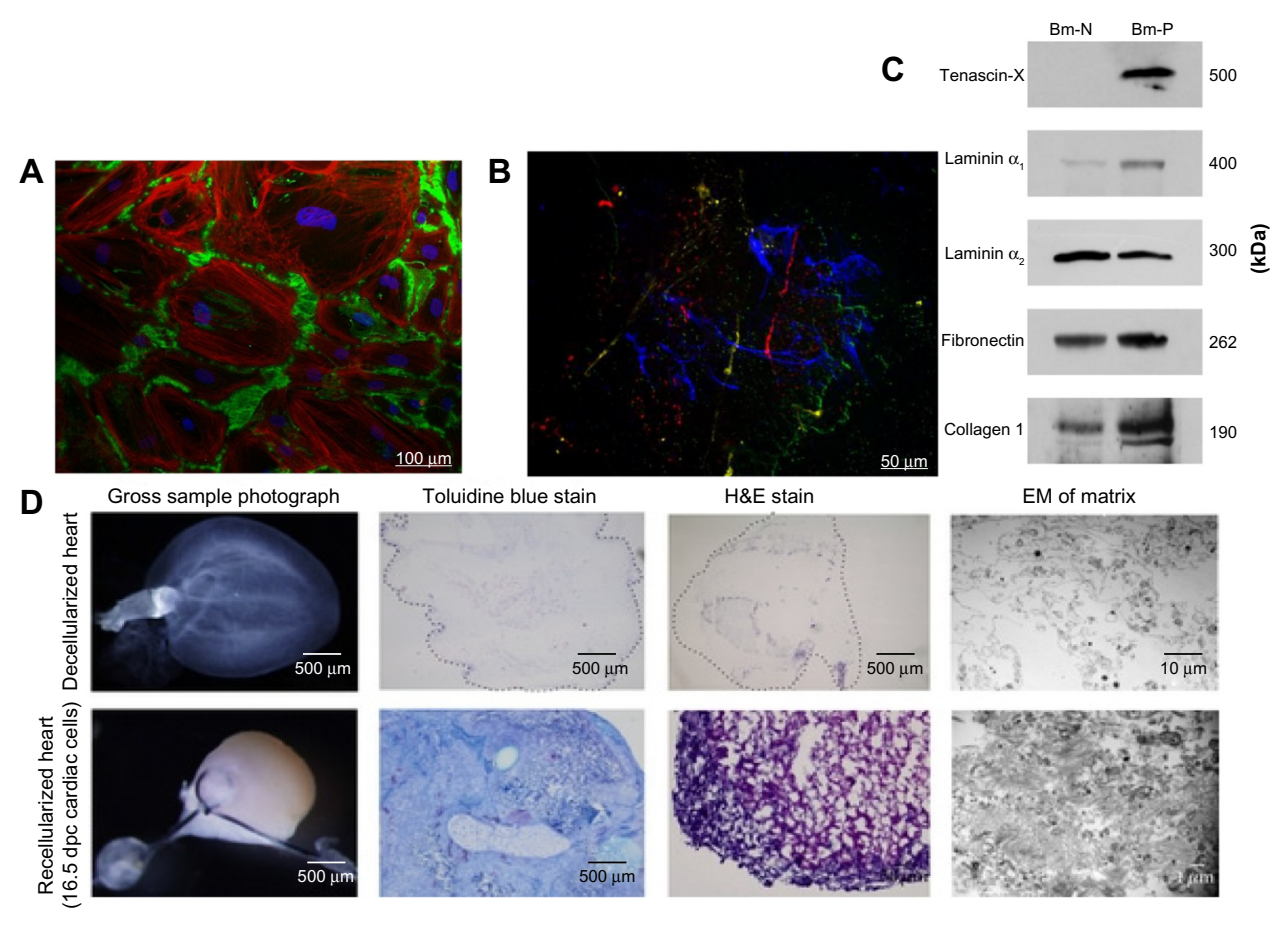

Figure 3 Biomimetic scaffolds

Notes: (A) Synthesis of biomatrix: fibroblasts isolated from samples of adult human heart were cultured in confluent state allowing for extracellular matrix (ECM) deposition in vitro. Representative image obtained by immunofluorescent labeling of actin filaments (red), cell nuclei (blue), and fibronectin (green). (B) Decellularization of biomatrix: after nonenzymatic removal of fibroblasts, ECM was observed under fluorescence microscope. Its composition was revealed by indirect immunofluorescent staining of representative ECM proteins: collagen IV (red), laminin (green), fibronectin (blue), and tenascin-C (yellow). (C) Immunoblotting of the decellularized biomatrix further confirmed the presence of these ECM-specific components in the biomatrix. Adapted from: Clotilde Castaldo, Franca Di Meglio, Rita Miraglia, et al., "Cardiac FibroblastDerived Extracellular Matrix (Biomatrix) as a Model for the Studies of Cardiac Primitive Cell Biological Properties in Normal and Pathological Adult Human Heart," BioMed Research International, vol. 2013, Article ID 352370, 7 pages, 2013. doi:10.1 I55/2013/352370. ${ }^{210}$ (D) Decellularization of embryonic cardiac tissue and recellularization with EI6.5 ventricular cells. The constructs create a favorable microenvironment for the cells to integrate and migrate on the scaffold. Macroscopic appearance of the supporting matrix changed from translucent to opaque following cell inclusion into the construct. This was further confirmed by hematoxylin and eosin (H\&E) and toluidine blue staining of the reseeded scaffolds, revealing a highly cellular environment on the host matrix. Collagen structures also became more physically compact after incubation of the scaffold with the cells, as shown by electron microscopy (EM). Adapted from Cree Chamberland, Almudena Martinez-Fernandez, Rosanna Beraldi, and Timothy J. Nelson, "Embryonic Decellularized Cardiac Scaffold Supports Embryonic Stem Cell Differentiation to Produce Beating Cardiac Tissue,” ISRN Stem Cells, vol. 20I4, Article ID 625I64, I0 pages, 20|4. doi:10.1155/2014/625164. ${ }^{211}$

Abbreviations: $\mathrm{Bm}-\mathrm{N}$, biomatrix from patient with a normal heart; Bm-P, biomatrix from patients with heart failure; dpc, day post conception. 
maintain transplanted cell function and survival. The three most common methods being investigated in this regard are biomimetic scaffolds, decellularized tissue scaffolds, and scaffold-free constructs.

\section{Biomimetic scaffolds}

Biomimetic scaffolds are made of either natural or synthetic polymers or a hybrid natural/synthetic copolymer. Natural polymers (as seen in Figure 3A), such as collagen, ${ }^{4,101}$ fibrin, ${ }^{102}$ alginate, ${ }^{103}$ Matrigel $^{\circledR},{ }^{104}$ chitosan, ${ }^{105}$ and hyaluronic acid $^{106}$ are biodegradable protein and polysaccharide molecules with a similar structure to the native component of the tissue extracellular matrix (ECM), making them more biocompatible and less immunogenic than synthetic polymers with a higher capacity for cell adhesion and influence on various cellular functions. ${ }^{106}$ The disadvantage of using natural polymer-based scaffolds is their limited mechanical and biodegradable properties that are not easily tailored.

On the other hand, synthetic polymers used for cardiac tissue engineering, such as polyethylene glycol, polyhydroxyethylmethacrylate, polylactide-glycolic acid, and poly(Nisopropylacrylamide), are easily tailored with predictable mechanical and chemical properties, but they may elicit an inflammatory response that might affect cell survival. ${ }^{106-109}$

In general, biomimetic scaffolds should be non-immunogenic and mechanically stable, mimic cardiac tissue flexibility, allow physiological electrical propagation, allow sufficient oxygen and nutrient delivery to cells, and have a degradation rate appropriate to the rate of native ECM replacement. ${ }^{97,110}$

Biomimetic scaffolds are used alone, as acellular scaffolds, or in combination with cells. ${ }^{111-114}$ Preparation and delivery can be further divided into either in vitro culture with cells to produce $3 \mathrm{D}$ engineered cardiac tissues ${ }^{115-117}$ or in vivo injection either directly in situ or with minimally invasive through catheter-based systems. ${ }^{103,118}$

The pathological process that leads to heart failure post-MI includes an initial inflammatory response, loss of cardiomyocytes, and loss of the ECM, which leads to scar formation and ventricular wall thinning. ${ }^{110,119,120}$ Injecting acellular biomimetic scaffolds at the site of MI, with or without bioactive molecules, provides structural mechanical support, ${ }^{121,122}$ decreases the amount of fibrosis and ventricular dilation, and promotes angiogenesis and the recruitment of native stem cells. ${ }^{101}$

Scaffolds combined with cells form environmental substrates to replace the ECM and enhances the retention and survival of the transplanted cells, with one study reporting the increased early survival and retention of cardiomyoblasts in collagen scaffolds transplanted into rats in which MI was induced compared with cardiomyoblasts in saline suspension. ${ }^{123}$

Selection of the cell type, scaffold material, and incorporation of bioactive molecules and bioreactors should be considered in constructing the optimal biomimetic scaffolds for treating cardiac diseases. "Bioreactors" are defined as specialized chambers designed to culture tissue-engineered constructs under controlled conditions. ${ }^{124,125}$ They have been developed to provide electrical and/or mechanical stimulation during tissue culture in order to promote uniform cellular distribution inside scaffolds, support the structure formation of 3D scaffold constructs, provide adequate oxygen and nutrient supply during culture, and help induce structural and functional cell maturation. ${ }^{126-128}$

For instance, it was found that electrical stimulation of neonatal rat myocyte in a collagen scaffold enhanced the conductive and contractile properties of the construct, increased cell alignment, and caused phenotypic changes resembling more mature myocytes compared with the nonstimulated scaffold. ${ }^{129}$

Recent advancements in nanomaterial science have further increased the efficiency of scaffolds. Davis et al used self-assembling peptides that rapidly form nanofibers and form a 3D scaffold at physiological $\mathrm{pH}$ and osmolarity. ${ }^{130}$ After injecting these peptides and the formation of the scaffold onto the free LV wall of adult male mice, the scaffold promoted the recruitment of endogenous endothelial and SMCs, and when compared with Matrigel scaffolds, fewer ECs were seen and they were localized around the edges. Furthermore, injecting neonatal mice cardiomyocytes with these self-assembling peptides resulted in the survival of these cells and the recruitment of endogenous cells that stained positively for myocyte progenitor markers. ${ }^{130}$

Also utilizing nanomaterial technology, Dvir et al incorporated gold nanowire within an alginate scaffold seeded with neonatal rat cardiomyocytes, which improved both electrical communication between cardiac cells and tissue formation, producing thicker tissue and better-aligned cells than cells in alginate scaffolds without the nanowires. ${ }^{131}$

Recently, there has been an interest in engineering cell-based cardiac pumps and tissue-engineered ventricles. Although technically challenging, such models can provide a potential concept for engineering a biological LV assist device or a biological drug pumping system. Furthermore, creating a hollow cardiac organoid structure can provide a flexible platform that can be adapted for the long-term study of cardiac pump function in vitro. Khait and Birla fabricated a cardiac pump prototype by surrounding a tubular graft with 
a monolayer of cardiomyocytes with the resulting generation of intraluminal pressure, ${ }^{125}$ while Lee et al fabricated a cardiac organoid chamber using neonatal rat myocytes seeded in a collagen/Matrigel matrix then casted on a mold with a balloon catheter to control chamber size. Spontaneous beating was observed after 7-10 days of culture and in a cryo-injury model of MI led to diminished global chamber pressure and decreased intrinsic pulse rate. ${ }^{132}$

\section{Decellularization to build a new heart for transplantation}

Whole-organ engineering is a promising field for the future of heart failure treatment. ${ }^{133}$ Since donor organs for transplantation are a limited resource, creating replacement organs from cadaveric allogeneic or xenogeneic sources could reduce the need for living donors. Tissue engineering also avoids problems with synthetic materials or mechanical devices for heart failure, which are subject to foreign-body reactions and hardware or software malfunction. The shape and structure of biologic scaffolds are also superior to those of synthetic matrices, and their complexity is not reproducible.

Thus the use of decellularized matrices has the potential to overcome the need to artificially recreate the conditions for ECM deposition. ${ }^{134-138}$ Tissues used to prepare these biologic scaffolds are typically autogenic, allogeneic, or xenogeneic in origin. ${ }^{139}$ Thus the decellularization technique (as seen in Figure 3 ) is very crucial to the success of the treatment.

From a tissue engineering perspective, the major objectives of decellularization are therefore to retain the structural integrity, composition and biological activity of the scaffold while completely removing the cellular and nuclear materials to eradicate any chance of unwanted immunological responses and other adverse side effects due to cross-presentation. ${ }^{140,141}$ If performed properly, the decellularization technique can be applied not only to tissues, but also to entire organs. ${ }^{142}$ Commonly used decellularized scaffolds in cardiac applications include adipose tissue, cartilages, and heart tissues of allogeneic, autologous, ${ }^{143-145}$ as well as xenogeneic origin. ${ }^{135,146}$ Studies show rapid repopulation with cardiomyocytes in natural matrix obtained from porcine tissues. ${ }^{147-150}$

The optimum method of decellularization remains variable, as it depends on the specific requirements of the application, such as high density, high pressure, and stiffness, which play vital roles in determining the method for decellularization. ${ }^{11,151}$ Chemical, enzymatic, microwave radiation, ${ }^{152}$ mechanical, and physical separations are the different methods used so far. Studies on the comparison of different techniques have been reported in the literature. ${ }^{153,154}$ It is known that a combination of physical, chemical, and enzymatic methods yields better results in the decellularization of both the whole organ and small tissues in cardiac applications. ${ }^{155,156}$ What is required for decellularization and recellularization is an organ to serve as a scaffold; a detergent, osmolar solution, or enzymatic solution to remove native cellular material; a choice of stem cells for repopulation; and a culture environment, or bioreactor, to promote new cell adhesion, growth, and integration.

Creating a clear scaffold for the reintroduction of stem cells is performed by coronary perfusion of a decellularizing agent. The choice of agent affects the level of antigenicity of the remaining tissue and its tensile strength, and an ideal decellularization process would remove antigenic material and preserve structural integrity. ${ }^{157}$ Detergents, organic solvents, and enzyme solutions that solubilize cell membranes can weaken the ECM. More vigorous agents, including ionic detergents such as sodium dodecyl sulfate (SDS) or enzymatic digestion with trypsin, are effective at removing antigens but can cause degradation of collagen. ${ }^{158,159}$ A gentler decellularization technique uses hypotonic saline to osmotically eliminate cells, but this can leave behind some antigenic material. ${ }^{160}$

SDS was used to decellularize a ventricular porcine myocardium, processed into hemocompatible and biocompatible hydrogels, and then injected into a porcine model with MI. ${ }^{161}$ A reduction in fibrosis, lack of thrombogenicity, and growth of cardiac muscles were observed. This was the first time that such percutaneous delivery of ECM using a transendocardial approach was carried out. ${ }^{162}$ Recent decellularization with SDS perfusion has been found successful in small animal organs and whole organs. ${ }^{155}$ With these promising results, such porcine heart models are being gradually translated to clinical applications. ${ }^{142,163}$

The choice of allogeneic or xenogeneic organ for decellularization can be difficult. Allogeneic hearts are size-appropriate and most structurally compatible for implantation. They are a limited resource and have human antigens, which can be recognized readily by immune defenses, and can transmit disease within the same species. Meanwhile, xenogeneic hearts have lesser degrees of anatomical fit but are an abundant resource and cause less inter-species disease transmission. Porcine hearts in particular are favored for a xenogeneic scaffold. ${ }^{164}$ Glutaraldehyde can be used to prevent acute immune rejection of the xenogeneic graft by cross-linking proteins, making them unrecognizable to host immune defenses, but delayed rejection is still possible. ${ }^{165}$ 
Ott et al pioneered the first bioengineered heart from decellularized organ matrix recellularized with stem cell infusion in 2008. The cellular components of rat hearts were dissolved in detergent solution, leaving an intact collagen skeleton. The hearts were injected with cardiac and vascular progenitor cells while supported in an organic reactor that simulated the preload and afterload of cardiac physiology. The result after 8 days of incubation was the detection of macroscopic contractions and overall pump strength equivalent to $2 \%$ of the adult heart or $25 \%$ of the function of a 16-week fetal heart. ${ }^{4}$

For larger models, porcine hearts have been decellularized for re-injection with cells $s^{121,142,163}$ and a human heart has been tested as a scaffold for repopulation with human mesenchymal cells and murine cardiomyocytes. ${ }^{166}$

Decellularized injectable scaffolds and solubilized pericardial gels are currently the two areas of research in which decellularization techniques have been found extremely helpful. ${ }^{134,167-172}$ Some of the other works include blends of natural and synthetic matrices to take advantage of both components. ${ }^{173}$ However, the technology of decellularization is still in its initial stage of development.

The future of this therapy will depend on achieving the correct combination of support structure and stem cells. One goal will be to provide a non-antigenic scaffold that will give durable, long-term support. Another will be to identify the mixture of cell lines that can provide contractility for adequate cardiac output and vascularity to sustain cardiac perfusion.

The major issue is the translation of basic research into clinical human use. Apart from its initial success, there have been reports of drawbacks with this method due to aging, incomplete decellularization, ${ }^{174}$ toxic effects, changes in biochemical properties, ${ }^{137}$ and changes in the cell's pathological immunogenicity. ${ }^{175-178}$ For instance, there has been a failure of clinically approved, tissue-engineered, decellularized porcine heart valves in pediatric patients; this was attributed to calcific depositions and incomplete decellularization of the implant. ${ }^{174}$

\section{Scaffold-free constructs}

Recent advancement in utilizing scaffolds as a substitute for the damaged ECM and supporting the viability and survival of cells used for cardiac tissue engineering is promising. However, the low cellular concentration inside the scaffold compared with the dense myocardial tissue of the native heart combined with the inflammatory reaction and fibrous tissue formation caused by scaffold degradation led to the consideration of building tissue engineering constructs without the use of scaffolds.

Shimizu et al developed a cell sheet engineering technique to construct scaffold-free 3D cardiac tissue. Using a temperature-responsive culture surface, they were able to detach two-dimensional (2D) myocardial layers as an intact confluent sheets and stack them to produce a 3D cardiac construct. ${ }^{173}$

Cell sheets are obtained by using specialized cell-culture surfaces that are covalently grafted with the temperatureresponsive polymer poly(N-isopropylacrylamide). ${ }^{180}$ The surface is hydrophobic and allows attachment of cells when the temperature is $37^{\circ} \mathrm{C}$; when the temperature is lowered to $32^{\circ} \mathrm{C}$, the surface becomes hydrophilic and causes the detachment of the cultured cells as an intact layer without disrupting the deposited ECM or the cell-to-cell junction proteins, ${ }^{181}$ both of which usually happen when using traditional enzymatic degradation substances such as trypsin.

When these 2D monolayers are stacked, they can rapidly attach and form cell-to-cell connections due to the presence of the intact deposited ECM. Shimizu et al also demonstrated that stacking monolayers of neonatal rat cardiomyocytes results in a spontaneously pulsating tissue with rapid electrical coupling between the layers, which was supported by the observation of the rapid formation of functional gap junctions. ${ }^{182}$

Miyahara et al used this technique to generate a monolayer of adipose tissue-derived MSCs. Four weeks after inducing $\mathrm{MI}$ in rats, they transplanted the 2D monolayer onto the scared myocardium. After transplantation, the sheet induced angiogenesis and grew to a thick striatum that included a few myocytes and prevented the progression of ventricular wall dilation and improved cardiac function. ${ }^{183}$

Similarly, Miyagawa et al transplanted 3D sheets of stacked monolayers of neonatal rat cardiomyocytes 2 weeks after inducing $\mathrm{MI}$ in rats. The 3D sheets became attached to the native myocardium, expressed connexin-43, showed angiogenesis and improved overall cardiac function. ${ }^{184}$

However, trying to apply such a method clinically is still challenging. The thickness limit for these 3D sheets was $80 \mu \mathrm{m}$, or three layers, as reported by Shimizu et al; ${ }^{182}$ stacking more than three layers at once resulted in core tissue necrosis. ${ }^{185}$ Several methods have been proposed to increase the vascularity and thickness of these sheets. Coculture with ECs and treatment with VEGF and in vitro vascularization bioreactors, allowing for a multi-step stacking of three-layer sheets, are examples of methods proposed to increase 3D sheet thickness. ${ }^{186}$ 


\section{Conclusion}

Stem cell therapy is likely to be a fundamental treatment strategy in the not-too-distant future. Traditional medical and surgical therapies have reached a point of maximal clinical utility and new strategies are required to treat the large population of patients with acute or chronic heart failure worldwide. Encouragingly, animal models have shown that stem cell therapy is safe and effective. As for the human clinical trials, many have demonstrated the safety and feasibility of the therapy; others have shown no significant effect, but, on the other hand, the majority of those trials have shown a trend of positive effect, whether on EF or on scar regression. What is needed now is further clinical testing and refinement to achieve better, more reliable, and more reproducible benefits. Larger randomized controlled trials could demonstrate the utility of stem cell therapy and comparison of studies could help identify the cell lineages that are the most effective, whether alone or in combination. With continued support, the proposed paracrine effects of implanted stem cells on resident stem cells could also be elucidated. Possible stem cells signaling factors therapy alone can potentially be employed, removing the time and burden of autologous stem cell harvest, or the antigenicity and rejection of allogeneic implantation. The need for the treatment of ischemic and nonischemic heart failure is highly demanded. Therefore, ongoing advancement in this new frontier is expected to continue. More organized infrastructure and collaborative research efforts, guided by evidence-based information, and adequate funding are needed to meet the important challenges ahead. However, the holy grail of tissue engineering and regenerative medicine seems to progressively take shape and hold tremendous promise to benefit humankind and treat presently incurable diseases.

\section{Acknowledgments}

The authors acknowledge the financial support to Dr ShumTim granted by the Natural Sciences and Engineering Research Council of Canada (NSERC) and Fonds de Recherché du Québec - Santé (FRSQ) - The Cell.

\section{Disclosure}

The authors declare no conflicts of interest in this work.

\section{References}

1. Lozano R, Naghavi M, Foreman K, et al. Global and regional mortality from 235 causes of death for 20 age groups in 1990 and 2010: a systematic analysis for the Global Burden of Disease Study 2010. Lancet. 2012; 380(9859):2095-2128.

2. Beltrami AP, Urbanek K, Kajstura J, et al. Evidence that human cardiac myocytes divide after myocardial infarction. NEng J Med. 2001;344(23): $1750-1757$.
3. Reddi AH, Huggins CB. Influence of geometry of transplanted tooth and bone on transformation of fibroblasts. Proc Soc Exp Biol Med. 1973; 143(3):634-637.

4. Ott HC, Matthiesen TS, Goh SK, et al. Perfusion-decellularized matrix: using nature's platform to engineer a bioartificial heart. Nat Med. 2008;14(2):213-221.

5. Paschos NK, Brown WE, Eswaramoorthy R, Hu JC, Athanasiou KA. Advances in tissue engineering through stem cell-based co-culture. J Tissue Eng Regen Med. 2014. Epub February 3.

6. Scorsin M, Hagege AA, Marotte F, et al. Does transplantation of cardiomyocytes improve function of infarcted myocardium? Circulation. 1997;96(9 Suppl):II-188-II-193.

7. Li RK, Jia ZQ, Weisel RD, et al. Cardiomyocyte transplantation improves heart function. Ann Thorac Med. 1996;62(3):654-660.

8. Xu C, Police S, Rao N, Carpenter MK. Characterization and enrichment of cardiomyocytes derived from human embryonic stem cells. Circ Res. 2002;91(6):501-508

9. Lee AS, Tang C, Cao F, et al. Effects of cell number on teratoma formation by human embryonic stem cells. Cell Cycle. 2009;8(16):2608-2612.

10. Gluckman E. Ten years of cord blood transplantation: from bench to bedside. Br J Haematol. 2009;147(2):192-199.

11. Henning RJ, Burgos JD, Vasko M, et al. Human cord blood cells and myocardial infarction: effect of dose and route of administration on infarct size. Cell Transplant. 2007;16(9):907-917.

12. Wang L, Deng J, Tian W, et al. Adipose-derived stem cells are an effective cell candidate for treatment of heart failure: an MR imaging study of rat hearts. Am J Physiol Heart Circ Physiol. 2009;297(3): H1020-H1031.

13. Valina C, Pinkernell K, Song YH, et al. Intracoronary administration of autologous adipose tissue-derived stem cells improves left ventricular function, perfusion, and remodelling after acute myocardial infarction. Eur Heart J. 2007;28(21):2667-2677.

14. Taylor DA, Atkins BZ, Hungspreugs P, et al. Regenerating functional myocardium: improved performance after skeletal myoblast transplantation. Nat Med. 1998;4(8):929-933.

15. Menasché P, Alfieri O, Janssens S, et al. The Myoblast Autologous Grafting in Ischemic Cardiomyopathy (MAGIC) trial: first randomized placebo-controlled study of myoblast transplantation. Circulation. 2008;117(9):1189-1200.

16. Dib N, Michler RE, Pagani FD, et al. Safety and feasibility of autologous myoblast transplantation in patients with ischemic cardiomyopathy: four-year follow-up. Circulation. 2005;112(12):1748-1755.

17. Orlic D, Kajstura J, Chimenti C, et al. Bone marrow cells regenerate infarcted myocardium. Nature. 2001;410(6829):701-705.

18. Laflamme MA, Chen KY, Naumova AV, et al. Cardiomyocytes derived from human embryonic stem cells in pro-survival factors enhance function of infarcted rat hearts. Nat Biotechnol. 2007;25(9):1015-1024.

19. Beltrami AP, Barlucchi L, Torella D. Adult cardiac stem cells are multipotent and support myocardial regeneration. Cell. 2003;114(6): 763-776.

20. Messina E, De Angelis L, Frati G. Isolation and expansion of adult cardiac stem cells from human and murine heart. Circ Res. 2004;95(9): 911-921.

21. Oh H, Bradfute SB, Gallardo TD. Cardiac progenitor cells from adult myocardium: homing, differentiation, and fusion after infarction. Proc Natl Acad Sci U S A. 2003;100(21):12313-12318.

22. Beltrami AP et al. Adult cardiac stem cells are multipotent and support myocardial regeneration. Cell. 2003;114(6):763-776

23. Weissman IL, Anderson DJ, Gage F. Stem and progenitor cells: origins, phenotypes, lineage commitments, and trans-differentiations. Annu Rev Cell Dev Biol. 2001;17:387-403.

24. Tang XL, Rokosh G, Sanganalmath SK, et al. Intracoronary administration of cardiac progenitor cells alleviates left ventricular dysfunction in rats with a 30-day-old infarction. Circulation. 2010;121(2): 293-305.

25. Bearzi C, Rota M, Hosoda T, et al. Human cardiac stem cells. Proc Natl Acad Sci U S A. 2007;104(35):14068-14073. 
26. Linke A, Müller P, Nurzynska D, et al. Stem cells in the dog heart are self-renewing, clonogenic, and multipotent and regenerate infarcted myocardium, improving cardiac function. Proc Natl Acad Sci U S A. 2005;102(25):8966-8971.

27. Urbanek K, Cesselli D, Rota M, et al. Stem cell niches in the adult mouse heart. Proc Natl Acad Sci U S A. 2006;103(24):9226-9231.

28. Bolli R, Chugh AR, D'Amario D, et al. Cardiac stem cells in patients with ischaemic cardiomyopathy (SCIPIO): initial results of a randomised phase 1 trial. Lancet. 2011;378(9806):1847-1857.

29. Pérez-Pomares JM, de la Pompa JL. Signaling during epicardium and coronary vessel development. Circ Res. 2011;109(12):1429-1442.

30. Tian X, Hu T, Zhang H, et al. Subepicardial endothelial cells invade the embryonic ventricle wall to form coronary arteries. Cell Res. 2013;23(9):1075-1090.

31. Cossette S, Misra R. The identification of different endothelial cell populations within the mouse proepicardium. Dev Dyn. 2011;240(10): 2344-2353.

32. Tomanek RJ. Formation of the coronary vasculature: a brief review. Cardiovasc Res. 1996;31 Spec No:E46-E51.

33. Kattman SJ, Witty AD, Gagliardi M, et al. Stage-specific optimization of activin/nodal and BMP signaling promotes cardiac differentiation of mouse and human pluripotent stem cell lines. Cell Stem Cell. 2011;8(2): 228-240.

34. Ye L, Zimmermann WH, Garry DJ, Zhang J. Patching the heart: cardiac repair from within and outside. Circ Res. 2013;113(7):922-932.

35. Li RK, Jia ZQ, Weisel RD, Mickle DA, Choi A, Yau TM. Survival and function of bioengineered cardiac grafts. Circulation. 1999; 100(19 Suppl):II63-II69.

36. Thomson JA, Itskovitz-Eldor J, Shapiro SS, et al. Embryonic stem cell lines derived from human blastocysts. Science. 1998;282(5391): $1145-1147$.

37. Yang L, Soonpaa MH, Adler ED, et al. Human cardiovascular progenitor cells develop from a KDR+ embryonic-stem-cell-derived population. Nature. 2008;453(7194):524-528.

38. Burridge PW, Keller G, Gold JD, Wu JC. Production of de novo cardiomyocytes: human pluripotent stem cell differentiation and direct reprogramming. Cell Stem Cell. 2012;10(1):16-28.

39. Paige SL, Osugi T, Afanasiev OK, Pabon L, Reinecke H, Murry CE. Endogenous Wnt/beta-catenin signaling is required for cardiac differentiation in human embryonic stem cells. PloS One. 2010;5(6):e11134.

40. Ueno S, Weidinger G, Osugi T, et al. Biphasic role for Wnt/beta-catenin signaling in cardiac specification in zebrafish and embryonic stem cells. Proc Natl Acad Sci U S A. 2007;104(23):9685-9690.

41. Naito AT, Shiojima I, Akazawa H, et al. Developmental stage-specific biphasic roles of Wnt/beta-catenin signaling in cardiomyogenesis and hematopoiesis. Proc Natl Acad Sci U S A. 2006;103(52): 19812-19817.

42. Lian X, Hsiao C, Wilson G, et al. Robust cardiomyocyte differentiation from human pluripotent stem cells via temporal modulation of canonical Wnt signaling. Proc Natl Acad Sci U S A. 2012;109(27): E1848-E1857.

43. Qian L, Huang Y, Spencer CI, et al. In vivo reprogramming of murine cardiac fibroblasts into induced cardiomyocytes. Nature. 2012; 485(7400):593-598.

44. Song K, Nam YJ, Luo X, et al. Heart repair by reprogramming nonmyocytes with cardiac transcription factors. Nature. 2012;485(7400): 599-604.

45. Chen JX, Krane M, Deutsch MA, Wang L, Rav-Acha M. Inefficient reprogramming of fibroblasts into cardiomyocytes using Gata4, Mef2c, and Tbx5. Circ Res. 2012;111(1):50-55.

46. Addis RC, Epstein JA. Induced regeneration - the progress and promise of direct reprogramming for heart repair. Nat Med. 2013;19(7): 829-836.

47. Kim C, Majdi M, Xia P, et al. Non-cardiomyocytes influence the electrophysiological maturation of human embryonic stem cell-derived cardiomyocytes during differentiation. Stem Cells Dev. 2010;19(6): 783-795.
48. Pasumarthi KB, Field LJ. Cardiomyocyte enrichment in differentiating ES cell cultures: strategies and applications. Methods Mol Biol. 2002;185:157-168.

49. Anderson D, Self T, Mellor IR, Goh G, Hill SJ, Denning C. Transgenic enrichment of cardiomyocytes from human embryonic stem cells. Mol Ther. 2007;15(11):2027-2036.

50. Uosaki H, Fukushima H, Takeuchi A, et al. Efficient and scalable purification of cardiomyocytes from human embryonic and induced pluripotent stem cells by VCAM1 surface expression. PloS One. 2011; 6(8):e23657.

51. Dubois NC, Craft AM, Sharma P, et al. SIRPA is a specific cell-surface marker for isolating cardiomyocytes derived from human pluripotent stem cells. Nat Biotechnol. 2011;29(11):1011-1018.

52. Tohyama S, Hattori F, Sano M, et al. Distinct metabolic flow enables large-scale purification of mouse and human pluripotent stem cellderived cardiomyocytes. Cell Stem Cell. 2013;12(1):127-137.

53. Fernandes S, Naumova AV, Zhu WZ, Laflamme MA, Gold J, Murry CE. Human embryonic stem cell-derived cardiomyocytes engraft but do not alter cardiac remodeling after chronic infarction in rats. $J \mathrm{Mol}$ Cell Cardiol. 2010;49(6):941-949.

54. Writing Group Members, Lloyd-Jones D, Adams RJ, et al; American Heart Association Statistics Committee and Stroke Statistics Subcommittee. Heart disease and stroke statistics - 2010 update: a report from the American Heart Association. Circulation. 2010;121(7): e46-e215.

55. Rumyantsev PP. Growth and Hyperplasia of Cardiac Muscle Cells. 1st ed. London: Taylor and Francis; 1991:1-371.

56. Soonpaa MH, Field LJ. Survey of studies examining mammalian cardiomyocyte DNA synthesis. Circ Res. 1998;83(1):15-26.

57. Anversa P, Kajstura J. Ventricular myocytes are not terminally differentiated in the adult mammalian heart. Circ Res. 1998;83(1):1-14.

58. Bergmann O, Bhardwaj RD, Bernard S, et al. Evidence for cardiomyocyte renewal in humans. Science. 2009;324(5923):98-102.

59. Michler RE. Stem cell therapy for heart failure. Cardiol Rev. 2014;22(3): $105-116$.

60. Ranganath SH, Levy O, Inamdar MS, Karp JM. Harnessing the mesenchymal stem cell secretome for the treatment of cardiovascular disease. Cell Stem Cell. 2012;10(3):244-258.

61. Dauwe DF, Janssens SP. Stem cell therapy for the treatment of myocardial infarction. Curr Pharm Des. 2011;17(30):3328-3340.

62. Teng CJ, Luo J, Chiu RC, Shum-Tim D. Massive mechanical loss of microspheres with direct intramyocardial injection in the beating heart: implications for cellular cardiomyoplasty. J Thorac Cardiovasc Surg. 2006;132(3):628-632.

63. Malliaras K, Li TS, Luthringer D, et al. Safety and efficacy of allogeneic cell therapy in infarcted rats transplanted with mismatched cardiospherederived cells. Circulation. 2012;125(1):100-112.

64. Abdel-Latif A, Bolli R, Tleyjeh IM, et al. Adult bone marrow-derived cells for cardiac repair: a systematic review and meta-analysis. Arch Intern Med. 2007;167(10):989-997.

65. Hofmann M, Wollert KC, Meyer GP, et al. Monitoring of bone marrow cell homing into the infarcted human myocardium. Circulation. 2005;111(17):2198-2202.

66. Ellison GM, Vicinanza C, Smith AJ, et al. Adult c-kit(pos) cardiac stem cells are necessary and sufficient for functional cardiac regeneration and repair. Cell. 2013;154(4):827-842.

67. Ellison GM, Torella D, Dellegrottaglie S, et al. Endogenous cardiac stem cell activation by insulin-like growth factor-1/hepatocyte growth factor intracoronary injection fosters survival and regeneration of the infarcted pig heart. J Am Coll Cardiol. 2011;58(9):977-986.

68. Waring CD, Vicinanza C, Papalamprou A, et al. The adult heart responds to increased workload with physiologic hypertrophy, cardiac stem cell activation, and new myocyte formation. Eur Heart J. 2014;35(39): 2722-2731.

69. Nadal-Ginard B, Ellison GM, Torella D. The cardiac stem cell compartment is indispensable for myocardial cell homeostasis, repair and regeneration in the adult. Stem Cell Res. 2014;13(3 Pt B):615-630. 
70. Houtgraaf JH, den Dekker WK, van Dalen BM, et al. First experience in humans using adipose tissue-derived regenerative cells in the treatment of patients with ST-segment elevation myocardial infarction. J Am Coll Cardiol. 2012;59(5):539-540.

71. Strauer BE, Brehm M, Zeus T, et al. Regeneration of human infarcted heart muscle by intracoronary autologous bone marrow cell transplantation in chronic coronary artery disease: the IACT Study. $\mathrm{J} \mathrm{Am} \mathrm{Coll}$ Cardiol. 2005;46(9):1651-1658.

72. Stamm C, Kleine HD, Choi YH, et al. Intramyocardial delivery of CD133+ bone marrow cells and coronary artery bypass grafting for chronic ischemic heart disease: safety and efficacy studies. $J$ Thorac Cardiovasc Surg. 2007;133(3):717-725.

73. Losordo DW, Schatz RA, White CJ, et al. Intramyocardial transplantation of autologous CD34+ stem cells for intractable angina: a phase I/IIa doubleblind, randomized controlled trial. Circulation. 2007;115(25): 3165-3172.

74. Povsic TJ, Junge C, Nada A, et al. A phase 3, randomized, doubleblinded, active-controlled, unblinded standard of care study assessing the efficacy and safety of intramyocardial autologous CD34+ cell administration in patients with refractory angina: design of the RENEW study. Am Heart J. 2013;165(6):854-861. e2.

75. van Ramshorst J, Bax JJ, Beeres SL, et al. Intramyocardial bone marrow cell injection for chronic myocardial ischemia: a randomized controlled trial. JAMA. 2009;301(19):1997-2004.

76. Zhao Q, Sun Y, Xia L, Chen A, Wang Z. Randomized study of mononuclear bone marrow cell transplantation in patients with coronary surgery. Ann Thorac Med. 2008;86(6):1833-1840.

77. Assmus B, Schächinger V, Teupe C, et al. Transplantation of Progenitor Cells and Regeneration Enhancement in Acute Myocardial Infarction (TOPCARE-AMI). Circulation. 2002;106(24):3009-3017.

78. Meyer GP, Wollert KC, Lotz J, et al. Intracoronary bone marrow cell transfer after myocardial infarction: eighteen months' follow-up data from the randomized, controlled BOOST (BOne marrOw transfer to enhance ST-elevation infarct regeneration) trial. Circulation. 2006; 113(10):1287-1294.

79. Wollert KC, Meyer GP, Lotz J, et al. Intracoronary autologous bone-marrow cell transfer after myocardial infarction: the BOOST randomised controlled clinical trial. Lancet. 2004;364(9429):141-148.

80. Lunde K, Solheim S, Aakhus S, et al. Intracoronary injection of mononuclear bone marrow cells in acute myocardial infarction. $N$ Engl J Med. 2006;355(12):1199-1209.

81. Assmus B, Tonn T, Seeger FH, et al. Red blood cell contamination of the final cell product impairs the efficacy of autologous bone marrow mononuclear cell therapy. J Am Coll Cardiol. 2010;55(13):1385-1394.

82. Schächinger V, Erbs S, Elsässer A, et al; REPAIR-AMI Investigators. Improved clinical outcome after intracoronary administration of bonemarrow-derived progenitor cells in acute myocardial infarction: final 1-year results of the REPAIR-AMI trial. Eur Heart J. 2006;27(23): 2775-2783.

83. Tendera M, Wojakowski W, Ruzyłł W, et al; REGENT Investigators. Intracoronary infusion of bone marrow-derived selected CD34+CXCR4+ cells and non-selected mononuclear cells in patients with acute STEMI and reduced left ventricular ejection fraction: results of randomized, multicentre Myocardial Regeneration by Intracoronary Infusion of Selected Population of Stem Cells in Acute Myocardial Infarction (REGENT) Trial. Eur Heart J. 2009;30(11):1313-1321.

84. Gyöngyösi M, Lang I, Dettke M, et al. Combined delivery approach of bone marrow mononuclear stem cells early and late after myocardial infarction: the MYSTAR prospective, randomized study. Nat Clin Pract Cardiovasc Med. 2009;6(1):70-81.

85. Sürder D, Manka R, Lo Cicero V, et al. Intracoronary injection of bone marrow-derived mononuclear cells early or late after acute myocardial infarction: effects on global left ventricular function. Circulation. 2013; 127(19):1968-1979.

86. Traverse JH, Henry TD, Ellis SG, et al; Cardiovascular Cell Therapy Research Network. Effect of intracoronary delivery of autologous bone marrow mononuclear cells 2 to 3 weeks following acute myocardial infarction on left ventricular function: the LateTIME randomized trial. JAMA. 2011;306(19):2110-2119.
87. Traverse JH, Henry TD, Vaughan DE, et al; Cardiovascular Cell Therapy Research Network. LateTIME: a phase-II, randomized, double-blinded, placebo-controlled, pilot trial evaluating the safety and effect of administration of bone marrow mononuclear cells 2 to 3 weeks after acute myocardial infarction. Tex Heart Inst $J$. 2010;37(4):412-420.

88. Makkar RR, Smith RR, Cheng K, et al. Intracoronary cardiospherederived cells for heart regeneration after myocardial infarction (CADUCEUS): a prospective, randomised phase 1 trial. Lancet. 2012; 379(9819):895-904.

89. Perin EC, Sanz-Ruiz R, Sánchez PL, et al. Adipose-derived regenerative cells in patients with ischemic cardiomyopathy: The PRECISE Trial. Am Heart J. 2014;168(1):88-95. e2.

90. Perin EC, Dohmann HF, Borojevic R, et al. Transendocardial, autologous bone marrow cell transplantation for severe, chronic ischemic heart failure. Circulation. 2003;107(18):2294-2302.

91. Perin EC, Dohmann HF, Borojevic R, et al. Improved exercise capacity and ischemia 6 and 12 months after transendocardial injection of autologous bone marrow mononuclear cells for ischemic cardiomyopathy. Circulation. 2004;110(11 Suppl 1):II213-II218.

92. Assmus B, Fischer-Rasokat U, Honold J, et al; TOPCARE-CHD Registry. Transcoronary transplantation of functionally competent BMCs is associated with a decrease in natriuretic peptide serum levels and improved survival of patients with chronic postinfarction heart failure: results of the TOPCARE-CHD Registry. Circ Res. 2007;100(8): 1234-1241.

93. Hare JM, Fishman JE, Gerstenblith G, et al. Comparison of allogeneic vs autologous bone marrow-derived mesenchymal stem cells delivered by transendocardial injection in patients with ischemic cardiomyopathy: the POSEIDON randomized trial. JAMA. 2012;308(22):2369-2379.

94. Strauer BE, Yousef M, Schannwell CM. The acute and long-term effects of intracoronary Stem cell Transplantation in 191 patients with chronic heARt failure: the STAR-heart study. Eur J Heart Fail. 2010;12(7): 721-729.

95. Fischer-Rasokat U, Assmus B, Seeger FH, et al. A pilot trial to assess potential effects of selective intracoronary bone marrow-derived progenitor cell infusion in patients with nonischemic dilated cardiomyopathy: final 1-year results of the transplantation of progenitor cells and functional regeneration enhancement pilot trial in patients with nonischemic dilated cardiomyopathy. Circ Heart Fail. 2009;2(5):417-423.

96. Patnaik SS, Wang B, Weed B, Wertheim JA, Liao J. Decellularized scaffolds: concepts, methodologies, and applications in cardiac tissue engineering and whole-organ regeneration. In: Liu Q, Wang H, editors. Tissue Regeneration: Where Nanostructure Meets Biology. Singapore: World Scientific; 2014:77-124.

97. Zimmermann W, Melnychenko I, Eschenhagen T. Engineered heart tissue for regeneration of diseased hearts. Biomaterials. 2004;25(9): 1639-1647.

98. Bursac N, Papadaki M, Cohen RJ, et al. Cardiac muscle tissue engineering: toward an in vitro model for electrophysiological studies. Am J Physiol. 1999;277(2 Pt 2):H433-H444.

99. Müller-Ehmsen J, Whittaker P, Kloner RA, et al. Survival and development of neonatal rat cardiomyocytes transplanted into adult myocardium. J Mol Cell Cardiol. 2002;34(2):107-116.

100. Reinecke H, Murry CE. Taking the death toll after cardiomyocyte grafting: a reminder of the importance of quantitative biology. $J \mathrm{Mol}$ Cell Cardiol. 2002;34(3):251-253.

101. Yang YL, Motte S, Kaufman LJ. Pore size variable type I collagen gels and their interaction with glioma cells. Biomaterials. 2010;31(21): 5678-5688.

102. Christman KL, Fok HH, Sievers RE, Fang Q, Lee RJ. Fibrin glue alone and skeletal myoblasts in a fibrin scaffold preserve cardiac function after myocardial infarction. Tissue Eng. 2004;10(3-4):403-409.

103. Landa N, Miller L, Feinberg MS, et al. Effect of injectable alginate implant on cardiac remodeling and function after recent and old infarcts in rat. Circulation. 2008;117(11):1388-1396. 
104. Giraud MN, Ayuni E, Cook S, Siepe M, Carrel TP, Tevaearai HT. Hydrogel-based engineered skeletal muscle grafts normalize heart function early after myocardial infarction. Artif Organs. 2008;32(9): 692-700.

105. Lu WN, Lü SH, Wang HB, et al. Functional improvement of infarcted heart by co-injection of embryonic stem cells with temperature-responsive chitosan hydrogel. Tissue Eng Part A. 2009;15(6):1437-1447.

106. Lutolf MP, Hubbell JA. Synthetic biomaterials as instructive extracellular microenvironments for morphogenesis in tissue engineering. Nat Biotechnol. 2005;23(1):47-55.

107. Dobner S, Bezuidenhout D, Govender P, Zilla P, Davies N. A synthetic non-degradable polyethylene glycol hydrogel retards adverse post-infarct left ventricular remodeling. J Card Fail. 2009;15(7):629-636.

108. Klouda L, Mikos AG. Thermoresponsive hydrogels in biomedical applications. Eur J Pharm Biopharm. 2008;68(1):34-45.

109. Nelson DM, Ma Z, Fujimoto KL, Hashizume R, Wagner WR. Intra-myocardial biomaterial injection therapy in the treatment of heart failure: Materials, outcomes and challenges. Acta Biomater. 2011;7(1):1-15.

110. Leor J, Amsalem Y, Cohen S. Cells, scaffolds, and molecules for myocardial tissue engineering. Pharmacol Ther. 2005;105(2):151-163.

111. Christman KL, Lee RJ. Biomaterials for the treatment of myocardial infarction. J Am Coll Cardiol. 2006;48(5):907-913.

112. Davis ME, Hsieh PC, Grodzinsky AJ, Lee RT. Custom design of the cardiac microenvironment with biomaterials. Circ Res. 2005;97(1): $8-15$.

113. Huang NF, Yu J, Sievers R, Li S, Lee RJ. Injectable biopolymers enhance angiogenesis after myocardial infarction. Tissue Eng. 2005;11(11-12):1860-1866.

114. Reffelmann T, Kloner RA. Cellular cardiomyoplasty - cardiomyocytes, skeletal myoblasts, or stem cells for regenerating myocardium and treatment of heart failure? Cardiovasc Res. 2003;58(2):358-368.

115. Kellar RS, Shepherd BR, Larson DF, Naughton GK, Williams SK. Cardiac patch constructed from human fibroblasts attenuates reduction in cardiac function after acute infarct. Tissue Eng. 2005;11(11-12): 1678-1687.

116. Robinson KA, Li J, Mathison M, et al. Extracellular matrix scaffold for cardiac repair. Circulation. 2005;112(9 Suppl):I135-I143.

117. Zimmermann WH, Melnychenko I, Wasmeier G, et al. Engineered heart tissue grafts improve systolic and diastolic function in infarcted rat hearts. Nat Med. 2006;12(4):452-458.

118. Leor J, Tuvia S, Guetta V, et al. Intracoronary injection of in situ forming alginate hydrogel reverses left ventricular remodeling after myocardial infarction in Swine. J Am Coll Cardiol. 2009;54(11): 1014-1023.

119. Deten A, Volz HC, Briest W, Zimmer HG. Cardiac cytokine expression is upregulated in the acute phase after myocardial infarction. Experimental studies in rats. Cardiovasc Res. 2002;55(2):329-340.

120. Yoshida M, Oh H. Stem cell engineering for cardiac tissue regeneration. Cardiology. 2010;115(3):191-193.

121. Singelyn JM, DeQuach JA, Seif-Naraghi SB, Littlefield RB, SchupMagoffin PJ, Christman KL. Naturally derived myocardial matrix as an injectable scaffold for cardiac tissue engineering. Biomaterials. 2009;30(29):5409-5416.

122. Zimmermann WH, Eschenhagen T. Cardiac tissue engineering for replacement therapy. Heart Fail Rev. 2003;8(3):259-269.

123. Kutschka I, Chen IY, Kofidis T, et al. Collagen matrices enhance survival of transplanted cardiomyoblasts and contribute to functional improvement of ischemic rat hearts. Circulation. 2006;114(1 Suppl): I167-I173

124. Koch MA, Vrij EJ, Engel E, Planell JA, Lacroix D. Perfusion cell seeding on large porous PLA/calcium phosphate composite scaffolds in a perfusion bioreactor system under varying perfusion parameters. J Biomed Mater Res A. 2010;95(4):1011-1018.

125. Dvir T, Timko BP, Brigham MD, et al. Nanowired three-dimensional cardiac patches. Nat Nanotechnol. 2011;6(11):720-725.
126. Bilodeau K, Mantovani D. Bioreactors for tissue engineering: focus on mechanical constraints. A comparative review. Tissue Eng. 2006;12(8):2367-2383.

127. Radisic M, Marsano A, Maidhof R, Wang Y, Vunjak-Novakovic G. Cardiac tissue engineering using perfusion bioreactor systems. Nat Protoc. 2008;3(4):719-738.

128. Tandon N, Marsano A, Cannizzaro C, Voldman J, Vunjak-Novakovic G. Design of electrical stimulation bioreactors for cardiac tissue engineering. Conf Proc IEEE Eng Med Biol Soc. 2008;2008: 3594-3597.

129. Radisic M, Park H, Shing H, et al. Functional assembly of engineered myocardium by electrical stimulation of cardiac myocytes cultured on scaffolds. Proc Natl Acad Sci U S A. 2004;101(52):18129-18134.

130. Davis ME, Motion JP, Narmoneva DA, et al. Injectable self-assembling peptide nanofibers create intramyocardial microenvironments for endothelial cells. Circulation. 2005;111(4):442-450.

131. Khait L, Birla RK. Cell-based cardiac pumps and tissue-engineered ventricles. Regen Med. 2007;2(4):391-406.

132. Lee EJ, Kim do E, Azeloglu EU, Costa KD. Engineered cardiac organoid chambers: toward a functional biological model ventricle. Tissue Eng Part A. 2008;14(2):215-225.

133. Badylak SF, Taylor D, Uygun K. Whole-organ tissue engineering: decellularization and recellularization of three-dimensional matrix scaffolds. Annu Rev Biomed Eng. 2011;13:27-53.

134. Singelyn JM, Christman KL. Injectable materials for the treatment of myocardial infarction and heart failure: the promise of decellularized matrices. J Cardiovasc Transl Res. 2010;3(5):478-486.

135. Schenke-Layland K, Vasilevski O, Opitz F, et al. Impact of decellularization of xenogeneic tissue on extracellular matrix integrity for tissue engineering of heart valves. J Struct Biol. 2003;143(3): 201-208.

136. Moroni F, Mirabella T. Decellularized matrices for cardiovascular tissue engineering. Am J Stem Cells. 2014;3(1):1-20.

137. Breuer CK, Mettler BA, Anthony T, Sales VL, Schoen FJ, Mayer JE. Application of tissue-engineering principles toward the development of a semilunar heart valve substitute. Tissue Eng. 2004;10(11-12): $1725-1736$

138. Iop L, Bonetti A, Naso F, et al. Decellularized allogeneic heart valves demonstrate self-regeneration potential after a long-term preclinical evaluation. PloS One. 2014;9(6):e99593.

139. Oberwallner B, Brodarac A, Choi YH, et al. Preparation of cardiac extracellular matrix scaffolds by decellularization of human myocardium. J Biomed Mater Res A. 2014;102(9):3263-3272.

140. Freytes DO, Stoner RM, Badylak SF. Uniaxial and biaxial properties of terminally sterilized porcine urinary bladder matrix scaffolds. J Biomed Mater Res B Appl Biomater. 2008;84(2):408-414.

141. Wang B, Borazjani A, Tahai M, et al. Fabrication of cardiac patch with decellularized porcine myocardial scaffold and bone marrow mononuclear cells. J Biomed Mater Res A. 2010;94(4):1100-1110.

142. Wainwright JM, Czajka CA, Patel UB, et al. Preparation of cardiac extracellular matrix from an intact porcine heart. Tissue Eng Part C Methods. 2010;16(3):525-532.

143. Ozawa T, Mickle DA, Weisel RD, Koyama N, Ozawa S, Li RK. Optimal biomaterial for creation of autologous cardiac grafts. Circulation. 2002;106(12 Suppl 1):I176-I182.

144. Weber B, Emmert MY, Schoenauer R, Brokopp C, Baumgartner L, Hoerstrup SP. Tissue engineering on matrix: future of autologous tissue replacement. Semin Immunopathol. 2011;33(3):307-315.

145. Zou Y, Zhang Y. Mechanical evaluation of decellularized porcine thoracic aorta. J Surg Res. 2012;175(2):359-368.

146. Song JJ, Ott HC. Organ engineering based on decellularized matrix scaffolds. Trends Mol Med. 2011;17(8):424-432.

147. Chang Y, Chen SC, Wei HJ, Wu TJ, Liang HC, Lai PH, et al. Tissue regeneration observed in a porous acellular bovine pericardium used to repair a myocardial defect in the right ventricle of a rat model J Thorac Cardiovasc Surg. 2005;130(3):705-711. 
148. Badylak SF, Kochupura PV, Cohen IS, Doronin SV, Saltman AE, Gilbert TW, et al. The use of extracellular matrix as an inductive scaffold for the partial replacement of functional myocardium. Cell Transplant. 2006;15:S29-S40.

149. Ota T, Gilbert TW, Badylak SF, Schwartzman D, Zenati MA. Electromechanical characterization of a tissue-engineered myocardial patch derived from extracellular matrix. J Thorac Cardiovasc Surg. 2007;133(4):979-985.

150. Robinson KA, Li J, Mathison M, Redkar A, Cui J, Chronos NA, et al. Extracellular matrix scaffold for cardiac repair. Circulation. 2005;112(9S):I135-I143.

151. Fu RH, Wang YC, Liu SP, et al. Decellularization and recellularization technologies in tissue engineering. Cell Transplant. 2014;23(4-5): 621-630.

152. AzhimA, NaritaY,Muramatsu K, MorimotoY,Tanaka M. Decellularization of living tissue using microwave chemical process for tissue-engineered scaffold applications. In: Lim CT, Goh JC, editors. International Conference on Biomedical Engineering Proceedings. Vol 31, 6th World Congress of Biomechanics (WCB 2010): August 1-6, 2010, Singapore: In Conjunction with 14th International Conference on Biomedical Engineering (ICBME) and 5th Asia Pacific Conference on Biomechanics (APBiomech). Berlin and Heidelberg: Springer; 2010:934-937.

153. Akhyari P, Aubin H, Gwanmesia P, et al. The quest for an optimized protocol for whole-heart decellularization: a comparison of three popular and a novel decellularization technique and their diverse effects on crucial extracellular matrix qualities. Tissue engineering. Part C Methods. 2011;17(9):915-926.

154. He M, Callanan A. Comparison of methods for whole-organ decellularization in tissue engineering of bioartificial organs. Tissue eng Part B Rev. 2013;19(3):194-208.

155. Guyette JP, Gilpin SE, Charest JM, Tapias LF, Ren X, Ott HC. Perfusion decellularization of whole organs. Nat Protoc. 2014;9:1451-1468.

156. Venkatasubramanian RT, Grassl ED, Barocas VH, Lafontaine D, Bischof JC. Effects of freezing and cryopreservation on the mechanical properties of arteries. Ann Biomed Eng. 2006;34(5):823-832.

157. Gilbert TW, Sellaro TL, Badylak SF. Decellularization of tissues and organs. Biomaterials. 2006;27(19):3675-3683.

158. Zang M, Zhang Q, Chang EI, Mathur AB, Yu P. Decellularized tracheal matrix scaffold for tissue engineering. Plast Reconstr Surg. 2012;130(3):532-540.

159. Yang M, Chen CZ, Wang XN, Zhu YB, Gu YJ. Favorable effects of the detergent and enzyme extraction method for preparing decellularized bovine pericardium scaffold for tissue engineered heart valves. J Biomed Mater Res B Appl Biomater. 2009;91(1):354-361.

160. Cissell DD, Hu JC, Griffiths LG, Athanasiou KA. Antigen removal for the production of biomechanically functional, xenogeneic tissue grafts. J Biomech. 2014;47(9):1987-1996.

161. Wong ML, Wong JL, Athanasiou KA, Griffiths LG. Stepwise solubilization-based antigen removal for xenogeneic scaffold generation in tissue engineering. Acta Biomater. 2013;9(5):6492-6501.

162. Seif-Naraghi SB, Singelyn JM, Salvatore MA, et al. Safety and efficacy of an injectable extracellular matrix hydrogel for treating myocardial infarction. Sci Transl Med. 2013;5(173):173ra125.

163. Weymann A, Loganathan S, Takahashi H, et al. Development and evaluation of a perfusion decellularization porcine heart model - generation of 3-dimensional myocardial neoscaffolds. Circ J. 2011;75(4):852-860.

164. Badylak SF. Xenogeneic extracellular matrix as a scaffold for tissue reconstruction. Transpl Immunol. 2004;12(3-4):367-377.

165. Manji RA, Zhu LF, Nijjar NK, et al. Glutaraldehyde-fixed bioprosthetic heart valve conduits calcify and fail from xenograft rejection. Circulation. 2006;114(4):318-327.

166. Sánchez Fernández PL, Fernández Santos ME, Costanza S, et al. Decelularización de corazones humanos para el desarrollo de matrices cardiacas que sirvan como soporte a la bioingeniería de tejidos cardiacos funcionales [Decellularization of human hearts for the development of heart matrices serve as a support for functional cardiac tissue bioengineering]. Abstract 31. Rev Esp Cardiol. 2011;64:Suppl 3:4. Spanish.
167. Seif-Naraghi SB, Salvatore MA, Schup-Magoffin PJ, Hu DP, Christman KL. Design and characterization of an injectable pericardial matrix gel: a potentially autologous scaffold for cardiac tissue engineering. Tissue Eng Part A. 2010;16(6):2017-2027.

168. Paul A, Binsalamah ZM, Khan AA, et al. A nanobiohybrid complex of recombinant baculovirus and Tat/DNA nanoparticles for delivery of Ang-1 transgene in myocardial infarction therapy. Biomaterials. 2011;32(32):8304-8318.

169. Paul A, Elias CB, Shum-Tim D, Prakash S. Bioactive baculovirus nanohybrids for stent based rapid vascular re-endothelialization. Sci Rep. 2013;3:2366.

170. Paul A, Hasan A, Kindi HA, et al. Injectable graphene oxide/hydrogelbased angiogenic gene delivery system for vasculogenesis and cardiac repair. ACS Nano. 2014;8(8):8050-8062.

171. Paul A, Hasan A, Rodes L, Sangaralingam M, Prakash S. Bioengineered baculoviruses as new class of therapeutics using micro and nanotechnologies: principles, prospects and challenges. Adv Drug Deliv Rev. 2014;71:115-130.

172. Paul A, Shao W, Abbasi S, Shum-Tim D, Prakash S. PAMAM dendrimer-baculovirus nanocomplex for microencapsulated adipose stem cell-gene therapy: in vitro and in vivo functional assessment. Mol Pharm. 2012;9(9):2479-2488.

173. Vunjak-Novakovic G, Tandon N, Godier A, et al. Challenges in cardiac tissue engineering. Tissue Eng Part B Rev. 2010;16(2):169-187.

174. Simon P, Kasimir MT, Seebacher G, et al. Early failure of the tissue engineered porcine heart valve SYNERGRAFT in pediatric patients. Eur J Cardiothorac Surg. 2003;23(6):1002-1006; discussion 1006.

175. Schoen FJ, Levy RJ. Calcification of tissue heart valve substitutes: progress toward understanding and prevention. Ann Thorac Med. 2005;79(3):1072-1080.

176. Sutherland FW, Perry TE, Yu Y, et al. From stem cells to viable autologous semilunar heart valve. Circulation. 2005;111(21):2783-2791.

177. Hawkins JA, Breinholt JP, Lambert LM, et al. Class I and class II anti-HLA antibodies after implantation of cryopreserved allograft material in pediatric patients. JThorac Cardiovasc Surg. 2000;119(2): 324-330.

178. Liang R, Woo SL, Takakura Y, Moon DK, Jia F, Abramowitch SD. Long-term effects of porcine small intestine submucosa on the healing of medial collateral ligament: a functional tissue engineering study. J Orthop Res. 2006;24(4):811-819.

179. Shimizu T, Yamato M, Isoi Y, et al. Fabrication of pulsatile cardiac tissue grafts using a novel 3-dimensional cell sheet manipulation technique and temperature-responsive cell culture surfaces. Circ Res. 2002;90(3):e40.

180. Okano T, Yamada N, Sakai H, Sakurai Y. A novel recovery system for cultured cells using plasma-treated polystyrene dishes grafted with poly(N-isopropylacrylamide). J Biomed Mater Res. 1993;27(10): 1243-1251.

181. Kushida A, Yamato M, Konno C, Kikuchi A, Sakurai Y, Okano T. Decrease in culture temperature releases monolayer endothelial cell sheets together with deposited fibronectin matrix from temperature-responsive culture surfaces. J Biomed Mater Res. 1999;45(4): 355-362.

182. Shimizu T, Sekine H, Yang J, et al. Polysurgery of cell sheet grafts overcomes diffusion limits to produce thick, vascularized myocardial tissues. FASEB J. 2006;20(6):708-710.

183. Miyahara Y, Nagaya N, Kataoka M, et al. Monolayered mesenchymal stem cells repair scarred myocardium after myocardial infarction. Nat Med. 2006;12(4):459-465.

184. Miyagawa S, Sawa Y, Sakakida S, et al. Tissue cardiomyoplasty using bioengineered contractile cardiomyocyte sheets to repair damaged myocardium: their integration with recipient myocardium. Transplantation. 2005;80(11):1586-1595.

185. Masuda S, Shimizu T, Yamato M, Okano T. Cell sheet engineering for heart tissue repair. Adv Drug Deliv Rev. 2008;60(2):277-285.

186. Sekine H, Shimizu T, Sakaguchi K, et al. In vitro fabrication of functional three-dimensional tissues with perfusable blood vessels. Nat Commun. 2013;4:1399. 
187. Takahashi K, Tanabe K, Ohnuki M, et al. Induction of pluripotent stem cells from adult human fibroblasts by defined factors. Cell. 2007; 131(5):861-872.

188. Didié M, Christalla P, Rubart M, et al. Parthenogenetic stem cells for tissue-engineered heart repair. J Clin Investig. 2013;123(3):1285-1298.

189. Zhang J, Klos M, Wilson GF, et al. Extracellular matrix promotes highly efficient cardiac differentiation of human pluripotent stem cells: the matrix sandwich method. Circ Res. 2012;111(9):1125-1136.

190. Gantz JA, Palpant NJ, Welikson RE, Hauschka SD, Murry CE, Laflamme MA. Targeted genomic integration of a selectable floxed dual fluorescence reporter in human embryonic stem cells. PloS One. 2012;7(10):e46971.

191. Kita-Matsuo H, Barcova M, Prigozhina N, et al. Lentiviral vectors and protocols for creation of stable hESC lines for fluorescent tracking and drug resistance selection of cardiomyocytes. PloS One. 2009; 4(4):e5046.

192. Kehat I, Khimovich L, Caspi O, et al. Electromechanical integration of cardiomyocytes derived from human embryonic stem cells. Nat Biotechnol. 2004;22(10):1282-1289.

193. Zhang D, Shadrin IY, Lam J, Xian H-Q, Snodgrass HR, Bursac N. Tissue-engineered cardiac patch for advanced functional maturation of human ESC-derived cardiomyocytes. Biomaterials. 2013;34(23): 5813-5820

194. Nunes SS, Miklas JW, Liu J, Aschar-Sobbi R, Xiao Y, Zhang B. Biowire: a platform for maturation of human pluripotent stem cell-derived cardiomyocytes. Nat Methods. 2013;10(8):781-787.

195. Tulloch NL, Muskheli V, Razumova MV, et al. Growth of engineered human myocardium with mechanical loading and vascular coculture. Circ Res. 2011;109(1):47-59.

196. Klug MG, Soonpaa MH, Koh GY, Field LJ. Genetically selected cardiomyocytes from differentiating embryonic stem cells form stable intracardiac grafts. J Clin Invest. 1996;98(1):216-224.

197. Kawamura M, Miyagawa S, Miki K, et al. Feasibility, safety, and therapeutic efficacy of human induced pluripotent stem cell-derived cardiomyocyte sheets in a porcine ischemic cardiomyopathy model. Circulation. 2013;126(11 Suppl 1):S29-S37.

198. Miki K, Uenaka H, Saito A, et al. Bioengineered myocardium derived from induced pluripotent stem cells improves cardiac function and attenuates cardiac remodeling following chronic myocardial infarction in rats. Stem Cells Transl Med. 2012;1(5):430-437.

199. Stevens KR, Kreutziger KL, Dupras SK, et al. Physiological function and transplantation of scaffold-free and vascularized human cardiac muscle tissue. Proc Natl Acad Sci U S A. 2009;106(39): 16568-16573.

200. Janssens S, Dubois C, Bogaert J, et al. Autologous bone marrowderived stem-cell transfer in patients with ST-segment elevation myocardial infarction: double-blind, randomised controlled trial. Lancet. 2006;367(9505):113-121.

201. Huikuri HV, Kervinen K, Niemelä M, et al; FINCELL Investigators. Effects of intracoronary injection of mononuclear bone marrow cells on left ventricular function, arrhythmia risk profile, and restenosis after thrombolytic therapy of acute myocardial infarction. Eur Heart J. 2008;29(22):2723-2732.
202. Hirsch A, Nijveldt R, van der Vleuten PA, et al; HEBE Investigators. Intracoronary infusion of mononuclear cells from bone marrow or peripheral blood compared with standard therapy in patients after acute myocardial infarction treated by primary percutaneous coronary intervention: results of the randomized controlled HEBE trial. Eur Heart J. 2011;32(14):1736-1747.

203. Traverse JH, Henry TD, Pepine CJ, et al; Cardiovascular Cell Therapy Research Network (CCTRN). Effect of the use and timing of bone marrow mononuclear cell delivery on left ventricular function after acute myocardial infarction: the TIME randomized trial. JAMA. 2012; 308(22):2380-2389.

204. Perin EC, Willerson JT, Pepine CJ, et al; Cardiovascular Cell Therapy Research Network (CCTRN). Effect of transendocardial delivery of autologous bone marrow mononuclear cells on functional capacity, left ventricular function, and perfusion in chronic heart failure: the FOCUS-CCTRN trial. JAMA. 2012;307(16):1717-1726.

205. Duckers HJ, Houtgraaf J, Hehrlein C, et al. Final results of a phase IIa, randomised, open-label trial to evaluate the percutaneous intramyocardial transplantation of autologous skeletal myoblasts in congestive heart failure patients: the SEISMIC trial. EuroIntervention. 2011;6(7):805-812.

206. Dib N, Dinsmore J, Lababidi Z, et al. One-year follow-up of feasibility and safety of the first US, randomized, controlled study using 3-dimensional guided catheter-based delivery of autologous skeletal myoblasts for ischemic cardiomyopathy (CAuSMIC study). JACC Cardiovasc Interv. 2009;2(1):9-16.

207. Ang KL, Chin D, Leyva F, et al. Randomized, controlled trial of intramuscular or intracoronary injection of autologous bone marrow cells into scarred myocardium during CABG versus CABG alone. Nat Clin Pract Cardiovasc Med. 2008;5(10):663-670.

208. Losordo DW, Henry TD, Davidson C, et al; ACT34-CMI Investigators. Intramyocardial, autologous CD34+ cell therapy for refractory angina. Circ Res. 2011;109(4):428-436.

209. Bartunek J, Behfar A, Dolatabadi D, et al. Cardiopoietic stem cell therapy in heart failure: the C-CURE (Cardiopoietic stem Cell therapy in heart failURE) multicenter randomized trial with lineage-specified biologics. J Am Coll Cardiol. 2013;61(23):2329-2338.

210. Castaldo C, Di Meglio F, Miraglia R, et al. Cardiac fibroblast-derived extracellular matrix (biomatrix) as a model for the studies of cardiac primitive cell biological properties in normal and pathological adult human heart. Biomed Res Int. 2013;2013:352370.

211. Chamberland C, Martinez-Fernandez A, Beraldi R, Nelson TJ. Embryonic decellularized cardiac scaffold supports embryonic stem cell differentiation to produce beating cardiac tissue. ISRN Stem Cells. 2014;2014(2014):Article ID 625164.
Stem Cells and Cloning: Advances and Applications

\section{Publish your work in this journal}

Stem Cells and Cloning: Advances and Applications is an international, peer-reviewed, open access journal. Areas of interest in stem cell research include: Embryonic stem cells; Adult stem cells; Blastocysts; Cordblood stem cells; Stem cell transformation and culture; Therapeutic cloning; Umbilical cord blood and bone marrow cells; Laboratory,
Dovepress

animal and human therapeutic studies; Philosophical and ethical issues related to stem cell research. This journal is indexed on CAS. The manuscript management system is completely online and includes a quick and fair peer-review system. Visit http://www.dovepress.com/ testimonials.php to read real quotes from published authors. 